\title{
EFFECT OF DISEASE OF THE LIVER AND BILIARY TRACT UPON THE PHOSPHATASE ACTIVITY OF THE SERUM
}

\author{
By ALEXANDER B. GUTMAN, KENNETH B. OLSON,1 ETHEL BENEDICT \\ GUTMAN, AND CHARLES A. FLOOD \\ (From the Departments of Medicine and Surgery, College of Physicians and Surgeons, \\ Columbia University and the Presbyterian Hospital, New York)
}

(Received for publication August 29, 1939)

The present study deals with the influence of common affections of the liver and biliary tract upon the level of serum phosphatase activity in the adult. It is an analysis of our observations during the period 1933 to 1939 on those patients with involvement of the liver or biliary tract in whom the diagnosis could be proven by exploration or necropsy, or when insusceptible of proof (as in the hepatitides), could be established with reasonable certainty by clinical methods. Some 350 cases satisfied these criteria: 79 adults with proven obstruction of the common bile duct; 75 cases of hepatitis of indeterminate etiology (" catarrhal" jaundice); 39 cases of jaundice following exposure to known hepatotoxic drugs; 15 cases of hemolytic jaundice; 45 patients with proven cirrhosis of the liver, exclusive of biliary cirrhosis; 46 patients with proven neoplastic involvement of the liver; 10 patients with proven liver abscess; 10 cases of proven chronic passive congestion of the liver, without significant " cardiac" cirrhosis; and 29 cases of miscellaneous disorders of the liver or biliary tract. The data in 123 of these patients have been reported elsewhere (1). We record here observations made subsequent to that report, together with a study of the distribution of values in our total experience.

On the basis of these empirical clinical data, we have attempted to define the clinical usefulness and limitations of the determination of serum phosphatase activity as applied to diseases of the liver and biliary tract. Three such applications of the method appear to be of promise: (1) as a supplementary aid to the clinical differential diagnosis of the several types of jaundice; (2) as an index to certain complications following surgical procedures on the biliary tract; (3) as a rela-

1 Supported by a grant from the Josiah Macy, Jr., Foundation. tively early indicator of metastases in patients known to have malignant tumors.

It may be stated at the outset that our data do not wholly support Roberts' disputed claim that by determining the phosphatase activity of the serum "toxic, infective and catarrhal jaundice may be readily distinguished from jaundice of the obstructive type" (2). We find, as have most previous investigators (3), that while patients with obstructive jaundice show appreciable elevations in serum phosphatase activity with reasonable consistency, increased serum phosphatase levels of the same order may be observed also in some patients with hepatitis. Whether or not the overlapping of values in the several types of jaundice is sufficient to invalidate the serum phosphatase determination as a practical aid in differential diagnosis is the crux of the problem under consideration and the chief impetus for our studies. These studies have led us to believe that, in general, the determination of serum phosphatase activity affords evidence of limited but definite value in the major practical problem presented by patients with jaundice: the decision between surgical intervention ("surgical jaundice") and conservative management (" medical jaundice"). This usefulness is, of course, contingent upon the recognition of specific deficiencies in the method, to be pointed out later, and upon a general appreciation of the limitations of any one means of investigation in so complex a phenomenon as jaundice. Reproducibility in technique of the serum phosphatase determination is another essential, since application of the method depends upon a comparison of levels of phosphatase activity.

We have attempted, further, to derive such generalizations regarding possible mechanisms regulating the serum phosphatase level in hepatic disease as would seem to be justified by the consistency of our data. Obviously, uncontrollable 
variables encountered in any such clinical study necessitate cautious interpretation. However, it may be said that, with certain unexplained exceptions, the level of phosphatase activity of the serum in the adult appears to be peculiarly sensitive to any significant compromise of the patency of the extra- or intrahepatic biliary system, but is relatively unaffected by even extensive liver parenchymal injury per se. The determination of serum phosphatase activity in this sense complements the so-called "liver function" tests, which afford a measure of injury to the liver parenchyma, and the dye retention tests, which are inapplicable in the presence of jaundice.

The absolute values reported in our tables and the empirical levels derived in our statistical analysis refer to the Bodansky method for the determination of serum phosphatase activity (4). In our hands, as in those of Bodansky, this method gives a range of 1 to 4 Bodansky units per $100 \mathrm{cc}$. serum for normal adults (1). Serum bilirubin was estimated by the method of Thannhauser and Andersen (5). The results of various other determinations are not recorded, with a few exceptions that bear directly upon the interpretation of serum phosphatase values.

RESULTS IN CASES 124 To $358^{2}$

\section{Jaundice due to obstruction of the extra- hepatic biliary tract}

A. Pre-operative values in 27 proven cases of common duct stone (Table IA); 19 proven cases of carcinoma of the head of the pancreas or of the extrahepatic biliary tract (Table IB); and 8 proven cases of obstruction of miscellaneous origin (Table IC). The phosphatase activity of the serum was definitely increased in every one of these 54 cases of obstructive jaundice. Initial values in 49 cases ranged from 113.1 to 10.9 Bodansky units per $100 \mathrm{cc}$. serum. Values of less than 10 Bodansky units were obtained in 5 patients, of whom 3 were found to have calculi in the common duct with incomplete obstruction; 1 was a typical case of carcinoma of the head of the pancreas with complete obstruction of the common bile duct; and 1 was a curious case of

2 To avoid confusion with the 123 cases previously reported (1), the patients in the present series are numbered beginning with 124 . carcinoma arising from the proximal end of the common bile duct, with complete obstruction. The serum phosphatase values subsequently rose in this instance as the serum bilirubin level fell, for reasons that were never explained. The patient was not studied in the last months of life when jaundice recurred.

The total cholesterol content of these sera is recorded for comparison with the serum bilirubin and phosphatase levels. The significance of this comparison will be considered in the discussion.

B. Post-operative serum phosphatase values, with special reference to persisting external biliary fistulae. Serum phosphatase activity was determined post-operatively in 11 patients of the present series, at intervals varying from 3 days to 9 months after surgical intervention. Usually a roughly parallel trend in serum phosphatase and bilirubin was observed post-operatively. But sometimes there was a dissociation in serum phosphatase and serum biliriubin levels as illustrated particularly by the following 3 patients who developed persistent external biliary fistulae after cholecystectomy. It will be noted that, when such a dissociation in serum phosphatase and serum bilirubin levels occurred, the increased level of serum phosphatase activity paralleled the course of clinical complications, whereas the serum bilirubin showed little or no rise.

T. G., aged 45, developed bile peritonitis following cholecystectomy without drainage. Subsequent exploration disclosed disruption of the ligated cystic duct stump. The serum bilirubin rose to $5.2 \mathrm{mgm}$. per cent, perhaps due to resorption of intraperitoneal bile, but the serum phosphatase level remained within essentially normal limits (4.7 Bodansky units) so long as bile drained freely into the abdominal cavity. After correction of the leak and establishment of temporary external biliary drainage, the jaundice eventually cleared, the biliary fistula gradually closed, the stools showed bile and the patient became afebrile. He returned later with chills, fever and malaise suggesting cholangeitis, the symptoms subsiding after several weeks. Similar episodes recurred for the next 6 months. Throughout this period, he never developed jaundice, but the serum phosphatase activity was persistently elevated, ranging from 22.5 to 36.0 Bodansky units per $100 \mathrm{cc}$. As the febrile attacks gradually subsided, the serum phosphatase values began to fall.

A. P. (Case 6), following cholecystectomy, developed a stricture of the common bile duct with serum bilirubin of $10.7 \mathrm{mgm}$. per cent and serum phosphatase activity of 25.2 Bodansky units per $100 \mathrm{cc}$. Plastic repair of the common duct and establishment of a biliary fistula re- 
sulted in subsidence of jaundice but convalescence was stormy until, a month later, a perihepatic abscess was drained. After several uneventful months, jaundice recurred (serum bilirubin $7.2 \mathrm{mgm}$. per cent) with a serum phosphatase level of 34.9 Bodansky units per $100 \mathrm{cc}$. Exploration disclosed cicatrization of the repaired common bile duct. External drainage of bile again resulted in subsidence of jaundice but with cessation of drainage, fever, chills and jaundice returned. For the next 2 years, intermittent closure of the biliary fistula was associated with similar episodes suggesting cholangeitis; the serum bilirubin fluctuating between 8.8 and $3.0 \mathrm{mgm}$. per cent, the serum phosphatase level remaining in the region of 30 Bodansky units. Finally, choledochoduodenostomy was performed (at which time biliary cirrhosis was noted) and this apparently effected adequate internal drainage of bile. The patient has been virtually asymptomatic for 1 year and the serum phosphatase has fallen to 18.3 Bodansky units per $100 \mathrm{cc}$. with a trace of icterus.

The last patient, R. R., aged 28, survived an even more complex sequence of post-cholecystectomy complications with an accompanying dissociation of serum phosphatase and bilirubin trends. In this instance, post-operative recurrence of severe jaundice suggested possible stricture

TABLE I

Summary of analyses of the blood in fifty-four cases of jaundice due to common bile duct obstruction (Diagnosis established at operation or autopsy in each instance)

\begin{tabular}{|c|c|c|c|c|c|c|c|c|c|}
\hline \multirow{3}{*}{ 睍 } & \multirow[b]{2}{*}{ 苾 } & \multirow[b]{2}{*}{ Cause of obstruction } & \multirow{2}{*}{ 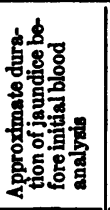 } & \multirow{2}{*}{ 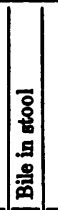 } & \multirow[b]{2}{*}{ Date } & \multicolumn{3}{|c|}{ Serum } & \multirow[b]{2}{*}{ Remarks } \\
\hline & & & & & & 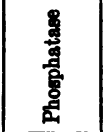 & 悬 & 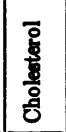 & \\
\hline & years & & & & & $\begin{array}{c}\text { Bodanety } \\
\text { unitas per } \\
100 \Leftrightarrow \text { \&. }\end{array}$ & $\begin{array}{c}\text { mom. } \\
\text { per } \\
100 \\
\infty .\end{array}$ & $\begin{array}{l}\text { mom. } \\
\text { per } \\
100 \\
\text { cc. }\end{array}$ & \\
\hline
\end{tabular}

A. CALCOUL DN COMnON BIW DOCT

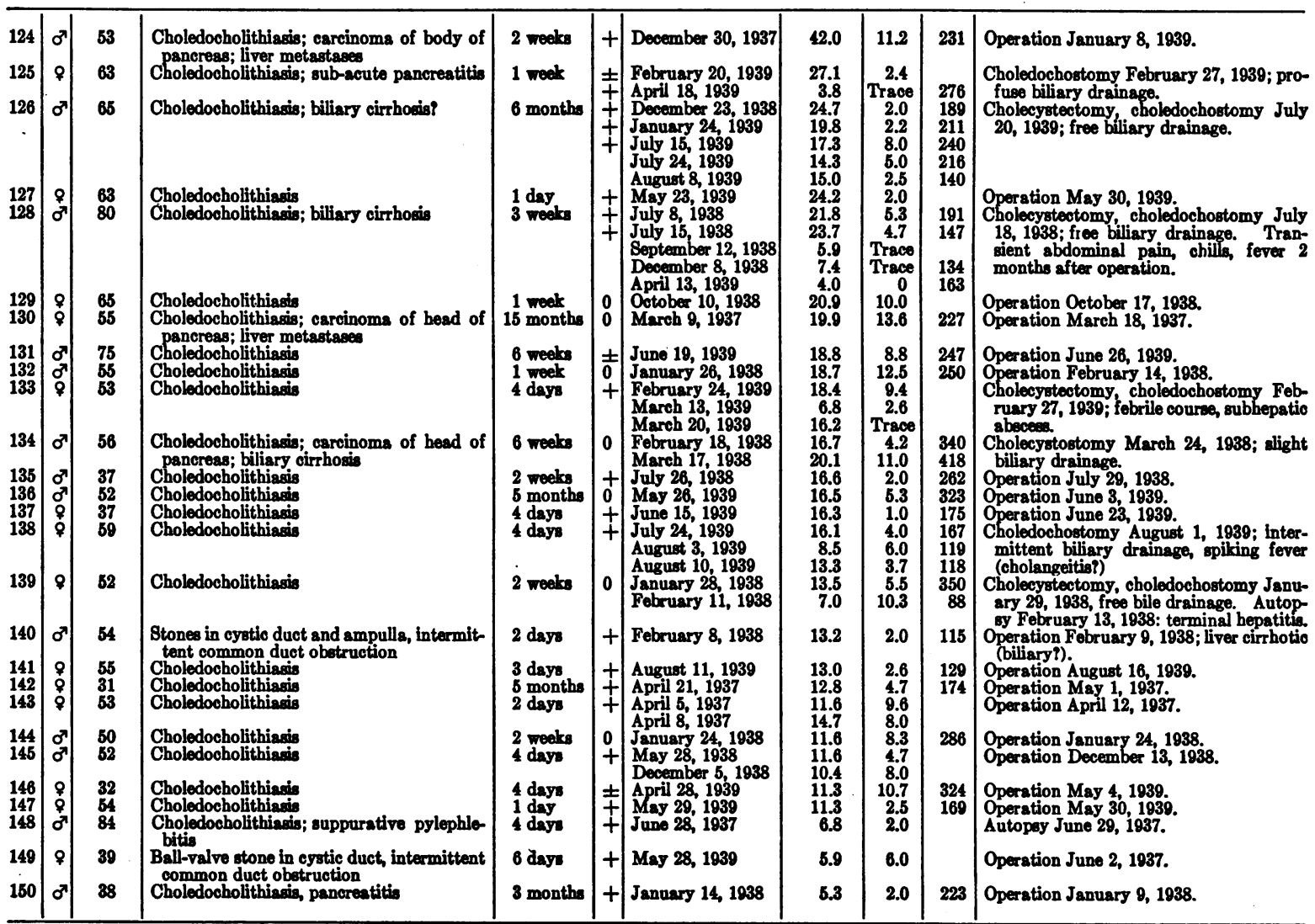


IABLE I-Continued

\begin{tabular}{|c|c|c|c|c|c|c|c|c|c|}
\hline \multirow[b]{2}{*}{ 悬 } & 8 & \multirow{2}{*}{ Cause of obstruction } & \multirow{2}{*}{ 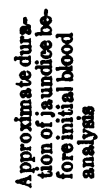 } & \multirow[b]{2}{*}{ 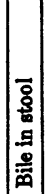 } & \multirow[b]{2}{*}{ Date } & \multicolumn{3}{|c|}{ Serum } & \multirow[b]{2}{*}{ Remarks } \\
\hline & 蒌 & & & & & 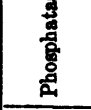 & $\begin{array}{l}\text { 量 } \\
\text { 豆 }\end{array}$ & $\begin{array}{l}\frac{8}{8} \\
\frac{8}{0} \\
80\end{array}$ & \\
\hline & yoars & & & & & 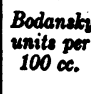 & $\begin{array}{l}\text { mom. } \\
\text { per } \\
100 \\
c c .\end{array}$ & $\begin{array}{l}\text { mpm. } \\
\text { per } \\
100 \\
\alpha .\end{array}$ & \\
\hline
\end{tabular}

B. CARCTNOMY OF HEAD OF PANCREAS OR OF EXTRAHMPATIC BLLARY TRACT

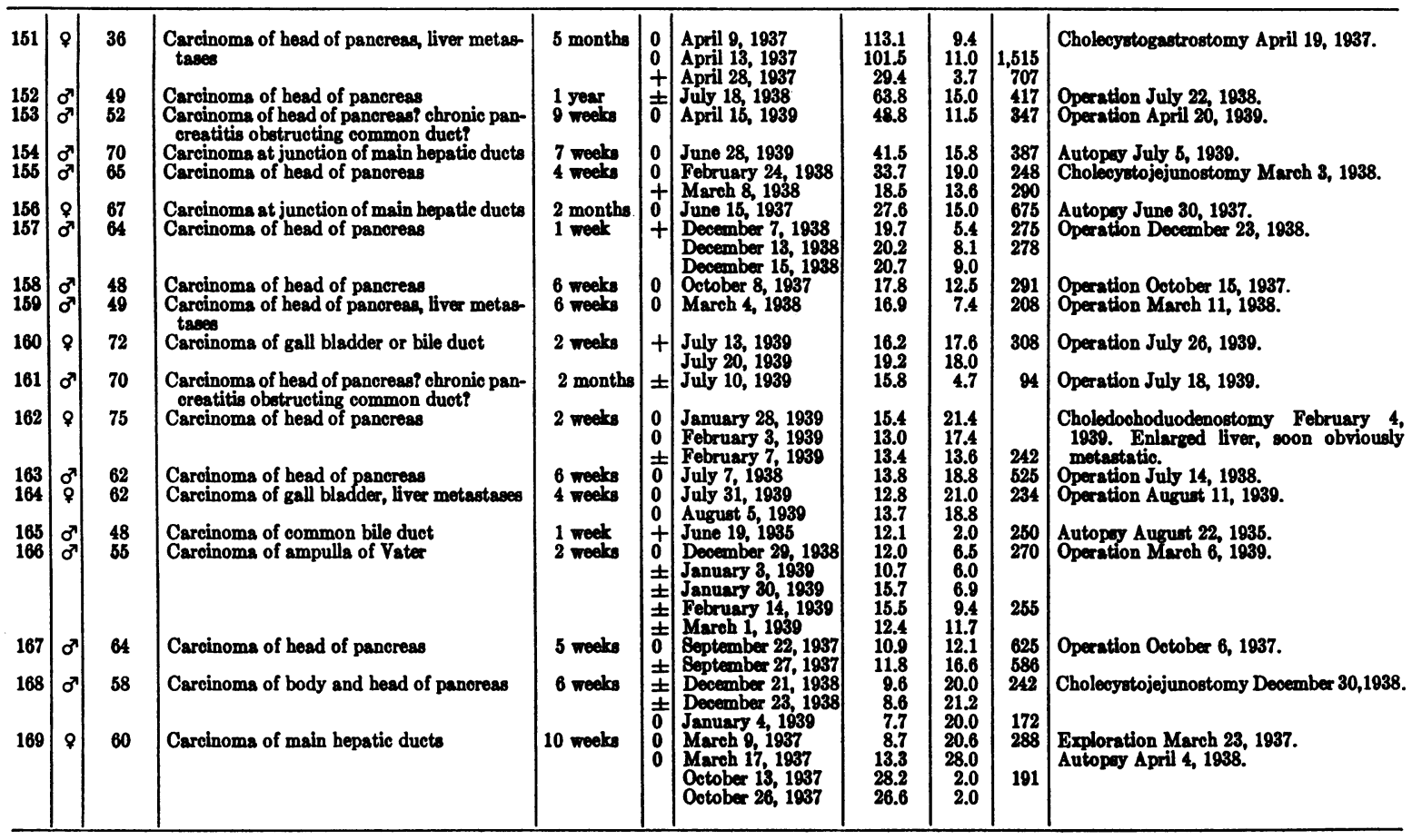

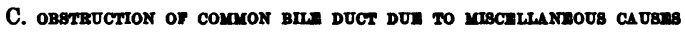

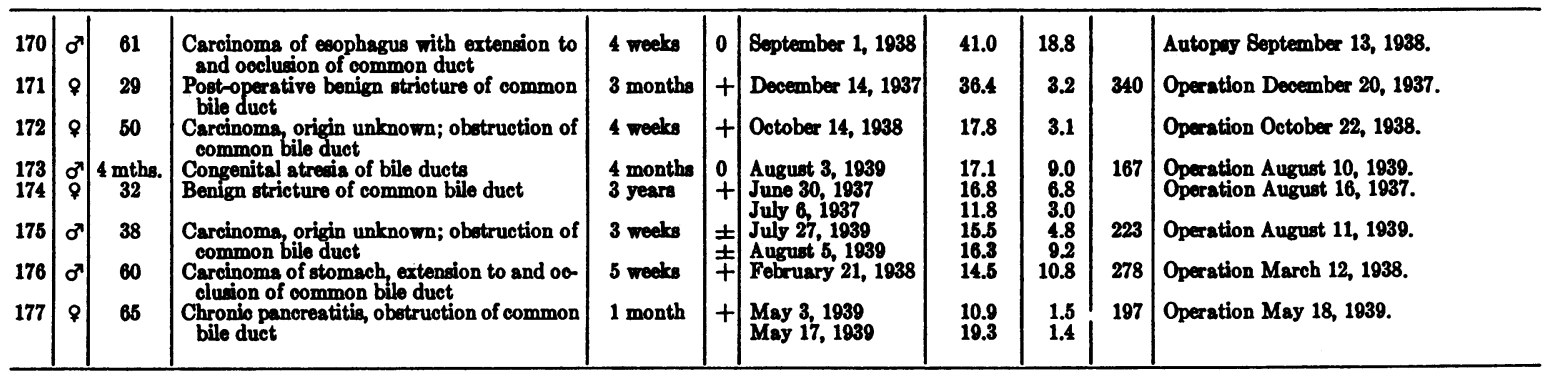

of the common bile duct, although the serum phosphatase was only 7.8 Bodansky units with a serum bilirubin of $9.2 \mathrm{mgm}$. per cent. Exploration disclosed a patent common duct of normal caliber but free of bile. The operative findings suggested that the jaundice was of intrahepatic origin, probably hepatitis. During this procedure, the duodenum was entered inadvertently and in the course of her stormy convalescence, a duodenal fistula developed. Through this bile drained freely, with subsidence of jaundice and return of the serum phosphatase to 4.8 Bodansky units per 100 cc. The fistula closed eventually but transient episodes of chills, fever and malaise have recurred at frequent intervals since. Significant clinical jaundice has not developed, yet the serum phosphatase level rose and has remained at about 18 Bodansky units per $100 \mathrm{cc}$. 


\section{Jaundice due to hepatitis}

Tables II and III together summarize our results in 67 cases of jaundice classified on clinical grounds as due to hepatitis. The distribution of serum phosphatase values in this group is not as

TABLE II

Summary of analyses of blood in forty-one cases of jaundice with a clinical course consistent with hepatitis of indeterminate etiology ("catarrhal" jaundice)

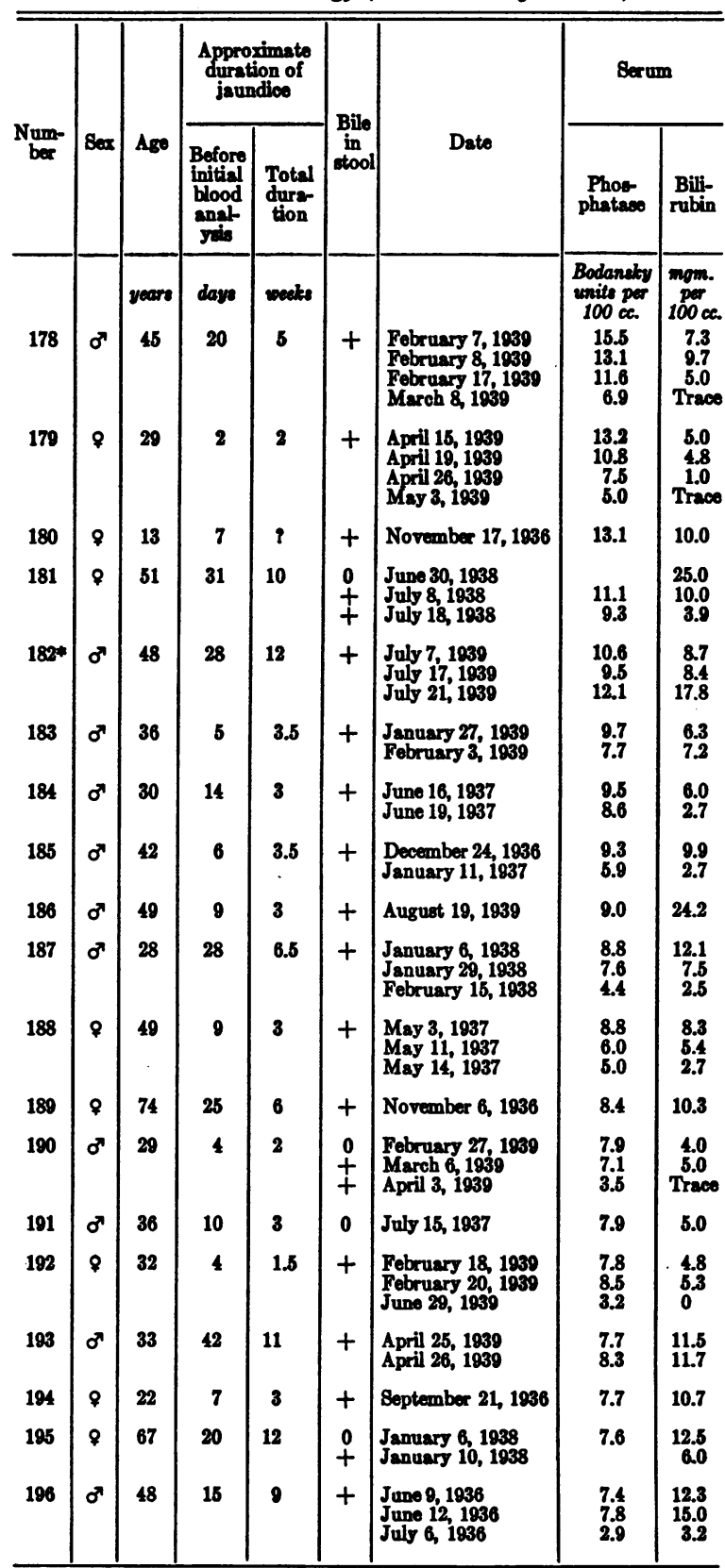

* Stone subsequently found in common duct.
TABLE II-Continued

\begin{tabular}{|c|c|c|c|c|c|c|c|c|}
\hline \multirow[b]{2}{*}{$\underset{\text { ber }}{\text { Num- }}$} & \multirow[b]{2}{*}{$\operatorname{Sex}$} & \multirow[b]{2}{*}{ Age } & \multicolumn{2}{|c|}{$\begin{array}{c}\text { Approximato } \\
\text { duration of } \\
\text { jaunfice. }\end{array}$} & \multirow{2}{*}{$\begin{array}{c}\text { Bile } \\
\text { in } \\
\text { stool }\end{array}$} & \multirow[b]{2}{*}{ Date } & \multicolumn{2}{|c|}{ Serum } \\
\hline & & & $\begin{array}{l}\text { Before } \\
\text { initial } \\
\text { blood } \\
\text { anat } \\
\text { yois }\end{array}$ & $\begin{array}{l}\text { Total } \\
\text { dura- } \\
\text { tion }\end{array}$ & & & $\begin{array}{c}\text { Phos- } \\
\text { phatase }\end{array}$ & $\begin{array}{l}\text { Buli- } \\
\text { rubin }\end{array}$ \\
\hline 197 & $\sigma^{\pi}$ & $\begin{array}{c}\text { yeare } \\
23\end{array}$ & $\begin{array}{c}\text { days } \\
3\end{array}$ & weeks & + & Oetober 15, 1936 & $\begin{array}{c}\text { Bodansky } \\
\text { units per } \\
100 \text { cc. } \\
7.4\end{array}$ & $\begin{array}{c}\text { mom. } \\
\text { per } \\
100 c . \\
2.0\end{array}$ \\
\hline 198 & ? & 43 & 7 & 5 & + & $\begin{array}{l}\text { Deoember 3, } 1937 \\
\text { December 15, } 1937\end{array}$ & $\begin{array}{l}7.3 \\
5.4\end{array}$ & $\begin{array}{l}11.7 \\
10.1\end{array}$ \\
\hline 199 & $\sigma^{\prime}$ & 22 & 3 & 2 & + & $\begin{array}{l}\text { March 14, } 1938 \\
\text { March 16, } 1938 \\
\text { March 22, } 1938\end{array}$ & $\begin{array}{l}7.3 \\
6.5 \\
5.0\end{array}$ & $\begin{array}{l}5.4 \\
8.1 \\
3.0\end{array}$ \\
\hline 200 & $\sigma^{\prime}$ & 24 & 4 & 1.5 & + & $\begin{array}{l}\text { Ootober 2, } 1937 \\
\text { October 5, } 1937\end{array}$ & $\begin{array}{l}7.2 \\
7.3\end{array}$ & $\begin{array}{l}6.1 \\
7.5\end{array}$ \\
\hline 201 & ? & 15 & 26 & 11 & + & $\begin{array}{l}\text { February 25, } 1939 \\
\text { February 28, } 1939 \\
\text { March 20, 1939 } \\
\text { April 3, 1939 }\end{array}$ & $\begin{array}{l}6.8 \\
6.6 \\
7.2 \\
7.4\end{array}$ & $\begin{array}{r}10.4 \\
8.8 \\
8.3 \\
7.0\end{array}$ \\
\hline 202 & 8 & 49 & 75 & 15 & + & $\begin{array}{l}\text { October 13, } 1937 \\
\text { October 21, } 1937 \\
\text { November 16,1937 } \\
\text { January 4, } 1938\end{array}$ & $\begin{array}{l}6.8 \\
4.2 \\
3.1 \\
2.6\end{array}$ & $\begin{array}{l}5.0 \\
2.3 \\
2.0 \\
\text { Trace }\end{array}$ \\
\hline 203 & 9 & 20 & 1 & 1.5 & + & February 11, 1938 & 6.7 & 3.8 \\
\hline 204 & 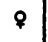 & 29 & 8 & 2.5 & + & Oetober 26, 1938 & 6.5 & 9.6 \\
\hline 205 & 8 & 28 & 8 & 3 & + & $\begin{array}{l}\text { Auguat 4, } 1938 \\
\text { August 15, } 1938\end{array}$ & $\begin{array}{l}6.4 \\
4.7\end{array}$ & $\begin{array}{l}7.8 \\
2.1\end{array}$ \\
\hline 206 & $\sigma^{\prime \prime}$ & 37 & 9 & 2.5 & $\stackrel{0}{+}$ & $\begin{array}{l}\text { November } 25,1938 \\
\text { December } 1,1938\end{array}$ & $\begin{array}{l}6.1 \\
4.5\end{array}$ & $\begin{array}{l}4.5 \\
2.0\end{array}$ \\
\hline 207 & $\sigma^{7}$ & 31 & 22 & 7 & 0 & March 2, 1939 & 3.8 & 19.0 \\
\hline 208 & ? & 34 & 5 & 3 & + & Julv 1, 1939 & 5.6 & 9.4 \\
\hline 200 & $\sigma^{\pi}$ & 39 & 15 & $3.5+$ & + & Oetober 25, 1937 & 5.6 & 4.4 \\
\hline 210 & $\sigma^{\prime}$ & 22 & 21 & 4 & + & $\begin{array}{l}\text { July 21, } 1938 \\
\text { July 25, } 1938\end{array}$ & 5.5 & $\begin{array}{r}15.0 \\
5.9\end{array}$ \\
\hline 211 & $\sigma^{\pi}$ & 34 & 8 & 2 & + & Auguet 0, 1938 & 5.4 & 9.4 \\
\hline 212 & $0^{\pi}$ & 42 & 14 & $5+$ & + & $\begin{array}{l}\text { August 13, } 1938 \\
\text { August 22, } 1938 \\
\text { August } 30,1938\end{array}$ & $\begin{array}{l}5.1 \\
6.7\end{array}$ & $\begin{array}{l}21.0 \\
19.0 \\
12.3\end{array}$ \\
\hline 213 & $\sigma^{7}$ & 23 & 3 & 1.5 & 0 & June 30, 1938 & 6.1 & 7.5 \\
\hline 214 & 9 & 24 & 3 & 2 & + & January 12, 1938 & 4.8 & 4.2 \\
\hline 215 & $\sigma^{\circ}$ & 28 & 3 & 2 & + & January 5, 1939 & 4.6 & 6.8 \\
\hline 216 & $\sigma^{\circ}$ & 32 & 23 & 13 & + & $\begin{array}{l}\text { October 28, } 1937 \\
\text { November 15, } 1937 \\
\text { December 16, } 1837\end{array}$ & $\begin{array}{l}4.2 \\
3.9 \\
3.5\end{array}$ & $\begin{array}{r}18.8 \\
5.0 \\
3.5\end{array}$ \\
\hline 217 & $\%$ & 37 & 4 & 1.5 & + & March 10, 1938 & 3.1 & 6.9 \\
\hline $218+$ & $\sigma^{\pi}$ & 19 & 15 & 3.5 & + & Fobruary 25, 1937 & 2.5 & 5.4 \\
\hline
\end{tabular}

† Subsequently found to have hemolytic jaundice, acquired.

sharply defined in relation to the empirical level of 10 Bodansky units as in the cases of obstructive jaundice: the phosphatase levels did not reach 10 Bodansky units per $100 \mathrm{cc}$. serum in 49 instances, whereas 18 cases exceeded this figure. However, the results show greater consistency if those patients whose jaundice followed upon the 
TABLE III

Summary of analyses of the blood in twenty-six cases of jaundice following exposure to known hepatotoxic agents

\begin{tabular}{|c|c|c|c|c|c|c|c|c|c|}
\hline \multirow{2}{*}{ Number } & \multirow{2}{*}{ Sex } & \multirow{2}{*}{ Age } & \multirow{2}{*}{ Cause of jaundice } & \multicolumn{2}{|c|}{$\begin{array}{l}\text { Approximate dura- } \\
\text { tion of jaundice }\end{array}$} & \multirow{2}{*}{$\begin{array}{l}\text { Uro- } \\
\text { bilin } \\
\text { in } \\
\text { stool }\end{array}$} & \multirow{2}{*}{ Date } & \multicolumn{2}{|c|}{ Serum } \\
\hline & & & & $\begin{array}{l}\text { Before ini- } \\
\text { tial blood } \\
\text { analysis }\end{array}$ & $\begin{array}{c}\text { Total } \\
\text { duration }\end{array}$ & & & Phosphatase & $\begin{array}{l}\text { Bill- } \\
\text { rubin }\end{array}$ \\
\hline 219 & \% & $\begin{array}{c}\text { years } \\
53\end{array}$ & . & $\begin{array}{c}\text { days } \\
7\end{array}$ & $\begin{array}{l}\text { weeks } \\
>7\end{array}$ & $\begin{array}{l} \pm \\
\pm \\
0 \\
0 \\
+\end{array}$ & $\begin{array}{l}\text { May } 31,1939 \\
\text { June } 5,1939 \\
\text { June } 15,1939 \\
\text { June 22, } 1939 \\
\text { June 29, } 1939\end{array}$ & $\begin{array}{c}\text { Bodansky } \\
\text { units per } \\
100 \text { cc. } \\
19.5 \\
30.9 \\
41.6 \\
31.5 \\
25.0\end{array}$ & 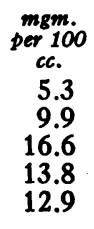 \\
\hline 220 & $\sigma^{7}$ & 29 & Arsenical therapy & 20 & 8 & $\begin{array}{l}0 \\
\pm \\
+ \\
+\end{array}$ & $\begin{array}{l}\text { May } 20,1938 \\
\text { June } 1,1938 \\
\text { June } 14,1938 \\
\text { June } 21,1938\end{array}$ & $\begin{array}{l}17.6 \\
13.8 \\
11.6 \\
11.8\end{array}$ & $\begin{array}{r}17.0 \\
15.0 \\
12.5 \\
9.4\end{array}$ \\
\hline 221 & $\sigma^{\pi}$ & 35 & Arsenical therapy & $70+$ & $14+$ & $\begin{array}{l}+ \\
+ \\
+\end{array}$ & $\begin{array}{l}\text { July } 24,1939 \\
\text { July } 28,1939 \\
\text { August } 18,1939\end{array}$ & $\begin{array}{l}16.7 \\
14.9 \\
24.7\end{array}$ & $\begin{array}{l}6.5 \\
6.5 \\
4.7\end{array}$ \\
\hline 222 & \% & 22 & Cinchophen & 20 & 8 & $\begin{array}{l}+ \\
+\end{array}$ & $\begin{array}{l}\text { April 21, } 1939 \\
\text { May 1, } 1939\end{array}$ & $\begin{array}{l}15.8 \\
13.8\end{array}$ & $\begin{array}{l}4.0 \\
2.0\end{array}$ \\
\hline 223 & \% & 25 & Arsenical therapy & 7 & $>3$ & + & June 8, 1939 & 14.5 & 17.0 \\
\hline 224 & 8 & 57 & Arsenical therapy & 7 & 8 & $\begin{array}{l}0 \\
+ \\
+ \\
+\end{array}$ & $\begin{array}{l}\text { January } 19,1937 \\
\text { January } 26,1937 \\
\text { February } 2,1937 \\
\text { March 4, 1937 }\end{array}$ & $\begin{array}{r}14.0 \\
7.8 \\
11.2 \\
6.8\end{array}$ & $\begin{array}{r}14.2 \\
15.0 \\
12.5 \\
2.0\end{array}$ \\
\hline 225 & q & 36 & Arsenical therapy & $60 \pm$ & 25 & $\begin{array}{l}0 \\
\pm \\
+ \\
+\end{array}$ & $\begin{array}{l}\text { July } 26,1938 \\
\text { September } 1,1938 \\
\text { September } 13,1938 \\
\text { September } 27,1938\end{array}$ & $\begin{array}{l}12.7 \\
18.5 \\
20.1 \\
13.9\end{array}$ & $\begin{array}{r}10.4 \\
15.0 \\
11.7 \\
9.4\end{array}$ \\
\hline 226 & $\sigma^{7}$ & 19 & Arsenical therapy & 7 & 4 & + & $\begin{array}{l}\text { March 9, } 1938 \\
\text { March 22, } 1938\end{array}$ & $\begin{array}{l}12.2 \\
14.3\end{array}$ & $\begin{array}{l}7.0 \\
2.2\end{array}$ \\
\hline 227 & $\sigma^{7}$ & 53 & Arsenical therapy & 9 & 20 & $\begin{array}{l}+ \\
+\end{array}$ & $\begin{array}{l}\text { March 17, } 1938 \\
\text { March 21, } 1938\end{array}$ & $\begin{array}{r}12.1 \\
9.0\end{array}$ & $\begin{array}{r}13.2 \\
7.4\end{array}$ \\
\hline 228 & $\sigma^{7}$ & 33 & Sulfanilamide & 2 & 1 & & $\begin{array}{l}\text { April } 8,1937 \\
\text { July } 10,1939 \\
\text { July } 16,1939\end{array}$ & $\begin{array}{r}11.3 \\
11.4 \\
9.1\end{array}$ & $\begin{array}{r}1.0 \\
\text { Trace }\end{array}$ \\
\hline 229 & $\sigma^{7}$ & 24 & Arsenical therapy & 6 & $2+$ & + & $\begin{array}{l}\text { March 27, } 1939 \\
\text { April 3, } 1939\end{array}$ & $\begin{array}{l}10.8 \\
20.4\end{array}$ & $\begin{array}{r}7.9 \\
11.5\end{array}$ \\
\hline 230 & $\sigma^{7}$ & 30 & Sulfanilamide & 5 & 5 & + & $\begin{array}{l}\text { May } 24,1937 \\
\text { June } 1,1937 \\
\text { June } 7,1937 \\
\text { June } 16,1937 \\
\text { June } 28,1937\end{array}$ & $\begin{array}{r}10.4 \\
11.9 \\
10.5 \\
10.9 \\
6.1\end{array}$ & $\begin{array}{l}2.0 \\
2.0 \\
7.1 \\
2.0 \\
1.0\end{array}$ \\
\hline 231 & $\sigma^{7}$ & 43 & Arsenical therapy & 63 & 13 & + & $\begin{array}{l}\text { July } 29,1939 \\
\text { August } 7,1939\end{array}$ & $\begin{array}{r}10.0 \\
9.0\end{array}$ & $\begin{array}{l}16.0 \\
16.5\end{array}$ \\
\hline 232 & $\%$ & 57 & Phosphorus* & 2 & 4 & $?$ & August 11, 1938 & 8.7 & 2.7 \\
\hline 233 & $\sigma^{x}$ & 26 & Arsenical therapy & $?$ & $?$ & + & $\begin{array}{l}\text { February } 3,1937 \\
\text { March } 9,1937\end{array}$ & $\begin{array}{l}8.4 \\
3.2\end{array}$ & $\begin{array}{c}8.3 \\
\text { Trace }\end{array}$ \\
\hline 234 & $\sigma^{7}$ & 46 & Arsenical therapy & 14 & 4 & + & $\begin{array}{l}\text { June } 14,1937 \\
\text { June } 24,1937\end{array}$ & $\begin{array}{l}8.2 \\
6.2\end{array}$ & $\begin{array}{l}4.2 \\
3.0\end{array}$ \\
\hline
\end{tabular}


TABLE III-Continued

\begin{tabular}{|c|c|c|c|c|c|c|c|c|c|}
\hline \multirow{2}{*}{ Number } & \multirow{2}{*}{ Sex } & \multirow{2}{*}{ Age } & \multirow{2}{*}{ Cause of jaundice } & \multicolumn{2}{|c|}{$\begin{array}{l}\text { Approximate dura- } \\
\text { tion of jaundice }\end{array}$} & \multirow{2}{*}{$\begin{array}{c}\text { Uro- } \\
\text { bilin } \\
\text { in } \\
\text { stool }\end{array}$} & \multirow{2}{*}{ Date } & \multicolumn{2}{|c|}{ Serum } \\
\hline & & & & $\begin{array}{l}\text { Before ini- } \\
\text { tial blood } \\
\text { analysis }\end{array}$ & $\begin{array}{c}\text { Total } \\
\text { duration }\end{array}$ & & & Phosphatase & $\begin{array}{l}\text { Bill- } \\
\text { rubin }\end{array}$ \\
\hline 235 & 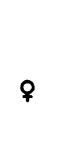 & $\begin{array}{c}\text { years } \\
38\end{array}$ & Sulfapyridine & $\begin{array}{c}\text { days } \\
1\end{array}$ & $\begin{array}{c}\text { weeks } \\
5\end{array}$ & + & $\begin{array}{l}\text { January } 24,1939 \\
\text { January 27, } 1939 \\
\text { February 1, } 1939\end{array}$ & $\begin{array}{c}\text { Bodansky } \\
\text { units per } \\
100 \text { ce. } \\
7.9 \\
13.6 \\
8.4\end{array}$ & $\begin{array}{c}\text { mgm. } \\
\text { per } 100 \\
\text { cc. } \\
6.5 \\
2.0 \\
\text { Trace }\end{array}$ \\
\hline 236 & $\sigma^{\pi}$ & 37 & Arsenical therapy & 15 & $4+$ & + & $\begin{array}{l}\text { January } 14,1937 \\
\text { January 18, } 1937 \\
\text { January 21, } 1939\end{array}$ & $\begin{array}{l}7.5 \\
4.6 \\
4.1\end{array}$ & $\begin{array}{l}15.0 \\
14.4 \\
11.2\end{array}$ \\
\hline 237 & 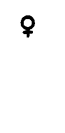 & 35 & Arsenical therapy & 35 & 12 & $\begin{array}{l}+ \\
+ \\
+ \\
+\end{array}$ & $\begin{array}{l}\text { June } 3,1938 \\
\text { June } 13,1938 \\
\text { June } 27,1938 \\
\text { July } 5,1938\end{array}$ & $\begin{array}{l}6.9 \\
8.7 \\
8.9 \\
8.6\end{array}$ & $\begin{array}{r}13.0 \\
9.4 \\
5.0 \\
4.3\end{array}$ \\
\hline 238 & $\sigma^{7}$ & 34 & Arsenical therapy & 16 & 4 & + & February 5, 1937 & 6.5 & 11.4 \\
\hline 239 & $\sigma^{\pi}$ & 71 & Carbon tetrachloride* & 7 & 1 & + & March 22, 1937 & 6.3 & 14.0 \\
\hline 240 & $\sigma^{\pi}$ & 22 & Arsenical therapy & $60 \pm$ & 10 & 0 & August 26, 1936 & 6.0 & 8.3 \\
\hline 241 & q & 32 & Sulfapyridine & 1 & $<1$ & + & $\begin{array}{l}\text { December } 27,1938 \\
\text { January } 5,1939\end{array}$ & $\begin{array}{l}4.9 \\
3.3\end{array}$ & $\begin{array}{l}3.8 \\
1.5\end{array}$ \\
\hline 242 & $q$ & 37 & Carbon tetrachloride & $?$ & $2 \pm$ & + & $\begin{array}{l}\text { May } 22,1937 \\
\text { May 29, } 1937 \\
\text { June } 2,1937 \\
\text { June } 8,1937\end{array}$ & $\begin{array}{l}4.7 \\
4.4 \\
5.0 \\
4.6\end{array}$ & $\begin{array}{l}4.5 \\
3.5 \\
4.0 \\
2.0\end{array}$ \\
\hline 243 & q & 47 & Sulfanilamide & $?$ & 1 & + & $\begin{array}{l}\text { December 24, } 1937 \\
\text { January } 3,1938\end{array}$ & $\begin{array}{l}4.1 \\
7.6\end{array}$ & $\begin{array}{c}\text { Trace } \\
2.0\end{array}$ \\
\hline 244 & $\sigma^{\pi}$ & 42 & Sulfanilamide & 1 & 3 & + & April 9, 1937 & 3.1 & 3.0 \\
\hline
\end{tabular}

* Fatal termination.

administration of hepatotoxic drugs are segregated from the miscellany of cases which it is convenient clinically to group together as " hepatitis." This division, for which there is other justification, ordinarily can be made without difficulty by reference to the case history.

Table II includes 41 patients with jaundice of indeterminate etiology in whom the clinical course, with few exceptions, was typical of so-called "catarrhal" jaundice. The phosphatase activity of the serum in all but 5 of these patients was less than 10 Bodansky units per $100 \mathrm{cc}$. The $5 \mathrm{ex}-$ ceptions include one 13-year-old patient whose serum phosphatase level of 13.1 Bodansky units was little, if at all, above the normal maximum for that age period. In many of the cases in this group with comparatively little rise in serum phosphatase activity, the degree of jaundice and the clinical course were indicative of severe paren- chymal involvement. In some, acholic stools were present for variable, occasionally protracted periods.

Table III includes 26 patients with jaundice following exposure to known hepatotoxic agents, for the most part luetics after intravenous administration of arsphenamine. In some of these, icterus developed rapidly early in the course of treatment, the highest values in Table III falling in this group. In others, icterus appeared as late as 6 months following cessation of treatment.

The dispersion in the cases comprising Table III is striking: no less than 14 cases (about half) presented serum phosphatase values greater than 10 Bodansky units at some time in the course of their jaundice, in one instance reaching a level of 41.6 Bodansky units per $100 \mathrm{cc}$. serum. There is some evidence that the dispersion in serum phosphatase values observed in arsphenamine 
jaundice may have clinical significance since many patients with markedly increased serum phosphatase activity also presented other peculiarities (clinical as well as in laboratory data) suggesting an obstructive rather than hepatogenous type of jaundice. For example, Hanger (6) pointed out that the sera of patients with arsphenamine jaundice and markedly increased serum phosphatase activity fail to flocculate cephalin-cholesterol emulsions, a sensitive test for hepatitis. Moreover, the serum cholesterol values in this group rose, in contrast to the usually normal or lowered levels in hepatogenous jaundice; the rise occurring after icterus had been present for some time and tending to persist after jaundice had subsided. Clinically, this group was characterized (6) by acute onset in the form of a typical delayed reaction to the second or third arsphenamine injection; by intense icterus and pruritus, acholic stools for long periods, and relative freedom from gastrointestinal upsets.

The cases in Table III with little rise in serum phosphatase activity, on the other hand, for the most part presented a clinical and laboratory picture more in keeping with that of hepatogenous jaundice.

\section{Hemolytic jaundice}

Table IV summarizes the results in 12 of our patients with hemolytic jaundice of diverse etiology. Case 245 was an infant who was deeply icteric at birth, the hyperbilirubinemia gradually subsiding within 6 weeks; an instance, apparently, of unusually severe and protracted "physiologi-

TABLE IV

Summary of analyses of the blood in twelve cases of hemolytic jaundice

\begin{tabular}{|c|c|c|c|c|c|c|}
\hline \multirow{2}{*}{ Number } & \multirow{2}{*}{ Sex } & \multirow{2}{*}{ Age } & \multirow{2}{*}{ Date } & \multicolumn{2}{|r|}{ Serum } & \multirow{2}{*}{ Diagnosis } \\
\hline & & & & $\begin{array}{l}\text { Phos- } \\
\text { phatase }\end{array}$ & Bilirubin & \\
\hline 245 & $\sigma^{7}$ & $\begin{array}{c}\text { years } \\
2 \text { weeks }\end{array}$ & $\begin{array}{l}\text { January } 22,1937 \\
\text { February } 2,1937\end{array}$ & $\begin{array}{l}\text { Bodansky } \\
\text { units per } \\
100 \text { cc. } \\
13.7\end{array}$ & $\begin{array}{c}\text { mgm. per } 100 \mathrm{cc} . \\
15.0 \text { (direct reaction) } \\
7.4\end{array}$ & $\begin{array}{l}\text { Unusually marked "physiological jaun- } \\
\text { dice" of newborn with protracted but } \\
\text { benign course. }\end{array}$ \\
\hline 246 & $\sigma^{7}$ & 28 & $\begin{array}{l}\text { December 19, } 1935 \\
\text { December 23, 1935 } \\
\text { December 27, 1935 } \\
\text { February 3,1936 } \\
\text { May } 12,1937 \\
\text { December } 11,1937 \\
\text { September 17, 1938 } \\
\text { September 23, 1938 }\end{array}$ & $\begin{array}{r}13.6 \\
9.9 \\
5.8 \\
3.5 \\
3.9 \\
3.8 \\
3.5\end{array}$ & $\begin{array}{l}18.9 \text { (direct reaction) } \\
10.0 \text { (direct reaction) } \\
9.4 \text { (direct reaction) } \\
5.4 \text { (biphasic reaction) } \\
6.1 \text { (indirect reaction) } \\
3.4 \text { (direct reaction) } \\
25.0 \text { (direct reaction) }\end{array}$ & $\begin{array}{l}\text { Sickle cell anemia with related bone } \\
\text { changes; hemolytic crises. }\end{array}$ \\
\hline 247 & $\sigma^{x}$ & 57 & May 1, 1939 & 3.9 & 5.4 (biphasic reaction) & $\begin{array}{l}\text { Familial (spherocytic) hemolytic jaun- } \\
\text { dice. }\end{array}$ \\
\hline 248 & q & 36 & June 20,1938 & 3.8 & 2.9 (indirect reaction) & $\begin{array}{l}\text { Familial (spherocytic) hemolytic jaun- } \\
\text { dice. }\end{array}$ \\
\hline 249 & $\sigma^{x}$ & 18 & May 5, 1937 & 2.6 & 4.7 (indirect reaction) & $\begin{array}{l}\text { Acquired hemolytic jaundice, cause } \\
\text { unknown; splenomegaly. }\end{array}$ \\
\hline 250 & \% & 58 & September 22,1938 & 2.6 & 2.0 (indirect reaction) & Pernicious anemia. \\
\hline 251 & $\sigma^{7}$ & 57 & May 13, 1938 & 2.5 & 3.0 (indirect reaction) & Pernicious anemia. \\
\hline 252 & ? & 70 & June 1, 1936 & 2.3 & 2.0 (indirect reaction) & Pernicious anemia. \\
\hline 253 & $\sigma^{7}$ & 62 & June 15, 1937 & 2.3 & 3.4 (indirect reaction) & Pernicious anemia. \\
\hline 254 & $\sigma^{7}$ & 35 & July 20, 1938 & 2.0 & 3.0 (indirect reaction) & $\begin{array}{l}\text { Familial (spherocytic) hemolytic jaun- } \\
\text { dice. }\end{array}$ \\
\hline 255 & $\sigma^{7}$ & 74 & May 27, 1938 & 2.0 & 2.0 (indirect reaction) & Pernicious anemia. \\
\hline 256 & \% & 61 & March 19, 1937 & 1.9 & 2.0 (indirect reaction) & Pernicious anemia. \\
\hline
\end{tabular}


cal" jaundice. The value 13.7 Bodansky units per $100 \mathrm{cc}$. is little, if at all, above the normal maximum for that age period. Case 246 was a colored male with severe sickle cell anemia and related skeletal changes who experienced several episodes of recurring jaundice. The first of these, in 1935, was an afebrile attack of deep jaundice which subsided spontaneously after 2 weeks. Marked enlargement and tenderness of the liver, choluria, normal stools and negative x-rays for opaque biliary calculi, characterized this episode, the precise nature of which remained uncertain. In 1938, severe jaundice recurred with a sharp drop in the erythrocyte count typical of "hemolytic crisis." Because of painful attacks suggesting biliary colic and $x$-ray evidence of gall bladder disease, the possibility of obstruction due to pigment stones was suggested. The serum phosphatase level was within normal limits despite very marked hyperbilirubinemia. Exploration revealed calcium bilirubinate " mud" in the gall bladder but no obstruction of the common bile duct, which was not dilated and through which saline could be irrigated freely.

As indicated in Table IV, the phosphatase activity of the serum is consistently within normal limits in hemolytic jaundice. There is no difficulty in establishing the diagnosis of hemolytic jaundice on other grounds, however, and we regard the use of the method in this type of jaundice as of chiefly theoretical interest; though in occasional obscure instances such as Case 246 the determination may be of distinct aid.

\section{Cirrhosis of the liver}

Table $\mathrm{V}$ summarizes our results in 30 patients with cirrhosis of the liver in whom the diagnosis could be established at necropsy or by liver biopsy. This is a heterogeneous group. The majority of subjects were chronic alcoholics and at necropsy many were found to have a fatty type of Laënnec's cirrhosis specified as "alcoholic" cirrhosis (7) ; when fatty degeneration was not striking but fibrosis was the chief abnormality, the findings are designated more generally as Laënnec's cirrhosis. The presence of extreme atrophy is recorded. The series further comprises 3 cases of "cardiac" cirrhosis in patients with long-standing cardiac failure; 3 cases of hemochromatosis; 2 cases of "toxic" cirrhosis associated with hyperthyroidism; and 1 case of schistosomiasis of the liver with cirrhotic changes. Cases 257 and 263 were relatively young persons. In the former the clinical course was that of sub-acute yellow liver atrophy, though the pathological findings were not so classified. Our proven instances of biliary cirrhosis were all patients with chronic obstructive jaundice and are included in Table I.

These patients for the most part presented the picture of hepatic cirrhosis in its more advanced stages. We have recorded the results of serum protein analyses (Howe's method was used) to afford another criterion of the degree of hepatic pathology. The highest value for serum phosphatase activity observed in this group was 20.3 Bodansky units per $100 \mathrm{cc}$. In only 6 patients were serum phosphatase levels of 10 Bodansky units or over obtained and 3 of these inconstantly exceeded that figure. Almost half of this group of advanced cirrhotics were found on at least one occasion to have essentially normal serum phosphatase levels. The results indicate that even advanced hepatic cirrhosis of the type included in Table V usually effects little rise in serum phosphatase activity. In biliary cirrhosis the values are quite consistently elevated.

\section{Neoplastic involvement of the liver}

Four proven cases of primary carcinoma of the liver (Table VIA); 10 cases of malignancy proven not to have liver involvement (Table $V I B)$; and 22 cases of malignancy with proven metastases to the liver (Table VIC). In 2 of the cases of primary carcinoma of the liver, the tumor had its origin in the intrahepatic biliary system (cholangioma), 2 arose from hepatic cells (hepatoma) in association with advanced Laënnec's cirrhosis. Not included in Table VI are 2 cases of carcinoma arising from the junction of the main hepatic ducts, which are recorded in Table IB (Cases 154 and 156) as instances of obstructive jaundice due to carcinoma at the origin of the common bile duct ; being in effect, if not literally, instances of extrahepatic duct obstruction. The serum phosphatase activity of the cases comprising Table VIA was distinctly elevated, the values ranging from 33.1 to 11.5 Bodansky units per $100 \mathrm{cc}$. In 2 previously recorded instances of 
primary carcinoma of the liver (Cases 99 and 118 ), the serum phosphatase levels were somewhat lower but still above those of most cases of uncomplicated hepatic cirrhosis. It would appear that the serum phosphatase activity tends to be higher in patients with primary carcinoma of the liver than in uncomplicated Laënnec's cirrhosis, with which the condition is most frequently confused clinically.

In considering patients with malignancy other than primary carcinoma of the liver, it is apparent from our data that the serum phosphatase level depends largely upon the presence or absence of metastases to the liver or skeleton. In Table VIB are recorded serum phosphatase values obtained in 10 patients with neoplasia shown at necropsy not to have involved the liver. Cases 291 and 292, however, had extensive osteoplastic metastases to bone and are included to illustrate the marked increase in serum phosphatase activity usually accompanying this type of metastatic spread. Cases 293 and 294 exhibited a significant rise in serum phosphatase activity although no metastases were noted in the liver or bones at

TABLE V

Summary of analyses of the blood in thirty proven cases of cirrhosis of the liver

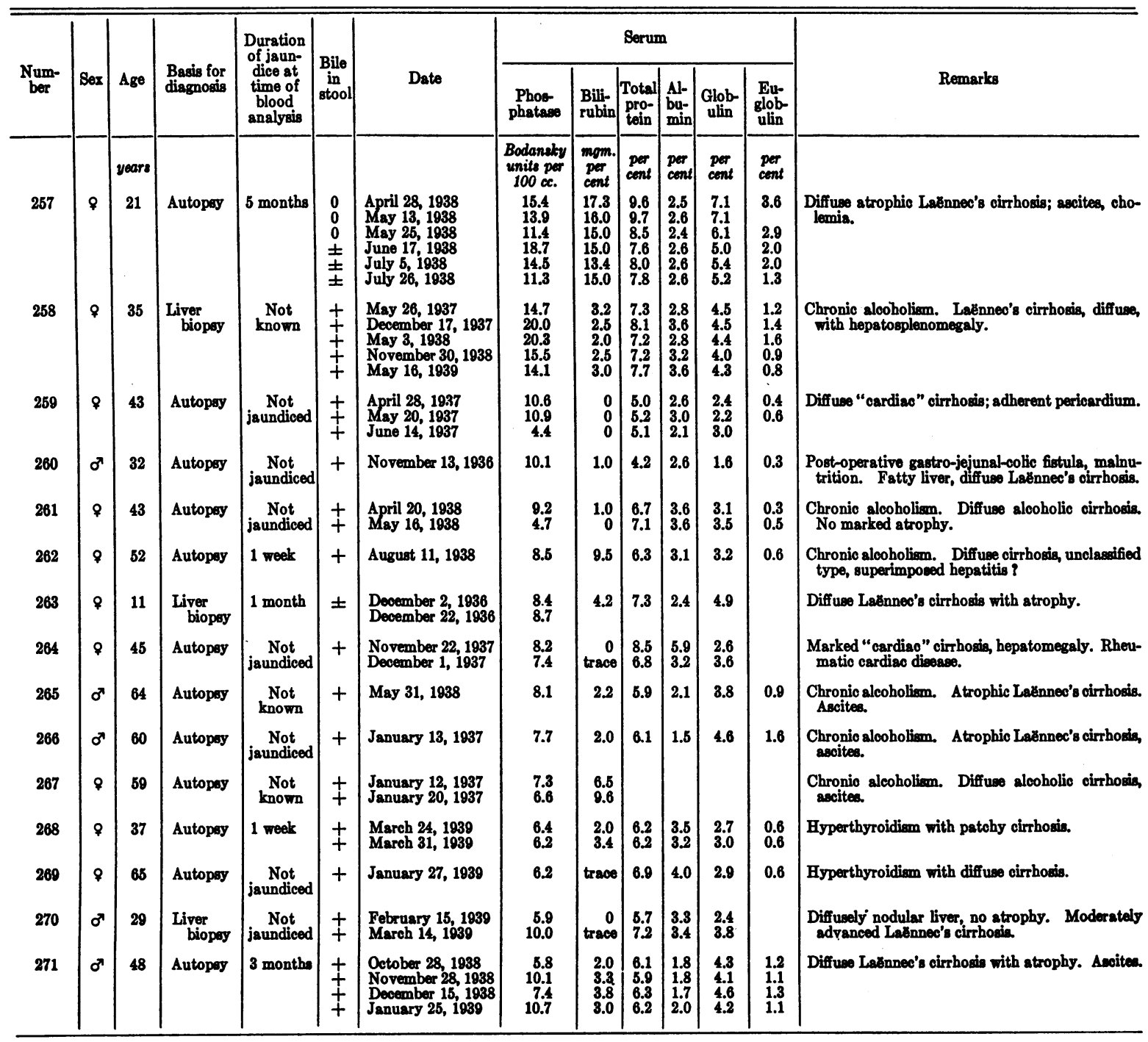


TABLE v-Continued

\begin{tabular}{|c|c|c|c|c|c|c|c|c|c|c|c|c|c|}
\hline \multirow{2}{*}{$\underset{\text { ber }}{\text { Num- }}$} & \multirow{2}{*}{ Sex } & \multirow{2}{*}{ Age } & \multirow{2}{*}{$\begin{array}{l}\text { Basis for } \\
\text { diagnosis }\end{array}$} & \multirow{2}{*}{$\begin{array}{l}\text { Duration } \\
\text { of jaun- } \\
\text { dice at } \\
\text { time of } \\
\text { blood } \\
\text { analygis }\end{array}$} & \multirow{2}{*}{$\begin{array}{c}\text { Bile } \\
\text { in } \\
\text { stool }\end{array}$} & \multirow{2}{*}{ Date } & \multicolumn{6}{|c|}{ Serum } & \multirow{2}{*}{ Remarks } \\
\hline & & & & & & & $\begin{array}{l}\text { Phos- } \\
\text { phatase }\end{array}$ & $\begin{array}{l}\text { Bili- } \\
\text { rubin }\end{array}$ & $\begin{array}{l}\text { Total } \\
\text { pro- } \\
\text { tein }\end{array}$ & $\mid \begin{array}{c}\mathrm{A}- \\
\mathrm{bu} \\
\mathrm{min}\end{array}$ & $\begin{array}{c}\text { Glob- } \\
\text { ulin }\end{array}$ & $\underset{\substack{\text { Eu- } \\
\text { glob- } \\
\text { ulin }}}{\text { ald }}$ & \\
\hline & & years & & & & & $\begin{array}{l}\text { Bodaneky } \\
\text { units per } \\
100 \mathrm{ce} \text {. }\end{array}$ & $\begin{array}{c}\text { mom. } \\
\text { per } \\
\text { cent }\end{array}$ & $\begin{array}{c}\text { per } \\
\text { cent }\end{array}$ & $\begin{array}{l}\text { per } \\
\text { cent }\end{array}$ & $\begin{array}{l}\text { per } \\
\text { cent }\end{array}$ & $\begin{array}{l}\text { per } \\
\text { cent }\end{array}$ & \\
\hline 272 & 8 & 43 & Autopey & $\underset{\text { jaundiced }}{\text { Not }}$ & $\begin{array}{l}+ \\
+ \\
+ \\
+\end{array}$ & $\begin{array}{l}\text { December 31, } 1936 \\
\text { January 11, } 1937 \\
\text { January 20, } 1937 \\
\text { January 27, } 1937 \\
\text { December 20,1937 } \\
\text { Fobruary 25, } 1938\end{array}$ & $\begin{array}{l}5.7 \\
6.9 \\
6.1 \\
5.4 \\
3.6 \\
3.6\end{array}$ & $\begin{array}{c}2.0 \\
\text { trace } \\
\text { tracec } \\
\text { trace } \\
2.0 \\
\text { trace }\end{array}$ & $\begin{array}{l}6.3 \\
8.2 \\
8.2 \\
8.7 \\
8.5 \\
6.8\end{array}$ & \begin{tabular}{l|}
2.2 \\
2.0 \\
2.2 \\
2.4 \\
2.1 \\
2.0
\end{tabular} & $\begin{array}{l}4.1 \\
6.2 \\
6.0 \\
6.3 \\
6.4 \\
4.8\end{array}$ & $\begin{array}{l}1.2 \\
2.7 \\
2.3 \\
2.7 \\
3.3 \\
2.4\end{array}$ & Atrophic Lašnnec's cirrhosis, diffuse. Ascites. \\
\hline 273 & व' & 47 & Autopey & $\begin{array}{c}\text { Not } \\
\text { jaundiced }\end{array}$ & + & March 16, 1937 & 4.7 & $\mathbf{0}$ & 7.0 & 3.9 & 3.1 & 0.4 & $\begin{array}{l}\text { Diffuse "cardiac" cirrhosis; coronary sclerosis, } \\
\text { hepatomegaly (congestive). }\end{array}$ \\
\hline 274 & $0^{\pi}$ & 57 & Autopey & 3 weeks & 0 & December 11, 1937 & 4.7 & 15.0 & 6.2 & 2.3 & 3.9 & 1.4 & $\begin{array}{l}\text { Diffuse Lağnnec's cirrhosis with atrophy; acute } \\
\text { cholangeitis; ascites. }\end{array}$ \\
\hline 275 & סיד & 60 & Autopey & 2 weeks & $\begin{array}{l}\mathbf{0} \\
\mathbf{0}\end{array}$ & $\begin{array}{l}\text { February 27, } 1939 \\
\text { March 2, } 1939\end{array}$ & $\begin{array}{l}4.4 \\
3.8\end{array}$ & $\begin{array}{l}24.2 \\
27.0\end{array}$ & $\begin{array}{l}6.7 \\
7.2\end{array}$ & $\begin{array}{l}2.3 \\
2.5\end{array}$ & $\begin{array}{l}4.4 \\
4.7\end{array}$ & $\begin{array}{l}1.8 \\
1.3\end{array}$ & $\begin{array}{l}\text { Chronic alcoholism. Atrophic Laënnec's cirrhosis, } \\
\text { diffuse. Ascites, cholecystitis. }\end{array}$ \\
\hline 276 & $\sigma^{7}$ & 54 & $\underset{\text { biopey }}{\text { Stin }}$ & $\underset{\text { jaundiced }}{\text { Not }}$ & + & June 7, 1937 & 4.2 & $\mathbf{0}$ & 7.2 & 4.2 & 3.0 & 0.4 & Hemochromstosia. Hepatomegaly, diabetes. \\
\hline 277 & 8 & 40 & Autopey & $\begin{array}{c}\text { Not } \\
\text { jaundiced }\end{array}$ & + & September 24, 1937 & 3.9 & $\mathbf{0}$ & 6.9 & 2.7 & 4.2 & 1.4 & Diffuse Laĕnnec's cirrhosis, early. Lues. \\
\hline 278 & \& & 54 & Autopey & 1 week & \pm & February 24, 1939 & 4.2 & 29.0 & 6.8 & 2.6 & 4.2 & 0.7 & $\begin{array}{l}\text { Chronic alcoholism, diffuse alcoholic cirrhosis; } \\
\text { ascites. }\end{array}$ \\
\hline 279 & $\sigma^{2}$ & 52 & Celiotomy & Not & + & January 25, 1937 & 3.6 & trace & 5.5 & 2.2 & 3.3 & 0.7 & Chronic alcoholism. Diffuse cirrhosis. \\
\hline 280 & 8 & 68 & Autopey & Not & + & January 15, 1937 & 3.4 & trace & 6.9 & 4.1 & 2.8 & 0.6 & Coarse lobular cirrhosis, luetic. \\
\hline 281 & $\sigma^{7}$ & 64 & Autopey & Not & + & January 14, 1936 & 3.3 & 2.0 & 6.5 & 3.6 & 2.9 & & $\begin{array}{l}\text { Hemochromatosis. Diffuse cirrhosis with hepa- } \\
\text { tomegaly. }\end{array}$ \\
\hline 282 & $\sigma^{7}$ & 59 & Autopey & $\underset{\text { known }}{\text { Not }}$ & + & June 8, 1937 & 3.2 & 6.5 & 7.1 & 3.6 & 3.5 & 1.2 & $\begin{array}{l}\text { Chronio alcoholism. Diffuse Laennec's cirrbosis, } \\
\text { no atrophy. }\end{array}$ \\
\hline 283 & $\sigma^{7}$ & 74 & Autopey & $\begin{array}{c}\text { Not } \\
\text { jaundiced }\end{array}$ & + & March 22, 1939 & 3.1 & 1.5 & 7.1 & 4.0 & 3.1 & 0.3 & Diffuse Lažnnec's cirrhosis, moderately advanced. \\
\hline 284 & $\sigma^{\prime}$ & 47 & Autopey & $\begin{array}{c}\text { Not } \\
\text { jaundiced }\end{array}$ & + & $\begin{array}{l}\text { September 20, } 1937 \\
\text { Docember 22, } 1937\end{array}$ & 2.7 & $\begin{array}{l}2.0 \\
1.0\end{array}$ & $\begin{array}{l}6.3 \\
6.3\end{array}$ & $\begin{array}{l}3.7 \\
4.2\end{array}$ & 2.6 & 0.1 & $\begin{array}{l}\text { Hemochromatosis. Hepatomegaly, marked oir- } \\
\text { rhosis, diabetes. }\end{array}$ \\
\hline 285 & 8 & 31 & $\underset{\text { biopey }}{\text { Liver }}$ & $\underset{\substack{\text { Not } \\
\text { known }}}{x_{0}}$ & + & 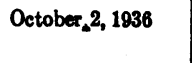 & 2.5 & 3.1 & & & & & Schistosomiasis; diffuse cirrhosis. \\
\hline 286 & q & 24 & $\underset{\text { biopey }}{\text { Liver }}$ & $\underset{\text { known }}{\text { Not }}$ & + & December 13,1935 & 1.5 & 3.3 & 5.5 & 3.4 & 2.1 & & Diff use Lånnec's cirrhosis, moderately advanced. \\
\hline
\end{tabular}

necropsy. This result is contrary to our usual experience, as indicated by the essentially normal values of the remaining cases in Table VIB.

Table VIC comprises 22 cases of neoplasm with proven metastatic involvement of the liver, exclusive of all subjects in whom the primary tumor originated from or by extension impinged upon the extrahepatic biliary tract. Excluded also are all patients with bone metastases demonstrable by $x$-ray or at necropsy, with the exception of Case 320. It is assumed that with these restrictions, a distinct increase in serum phosphatase activity may be attributed to the presence of secondary metastases to the liver.

The serum phosphatase level was found to be variable in this group, ranging from 23.9 to 4.0 Bodansky units per $100 \mathrm{cc}$. The values in 17 cases exceeded the maximum we usually find in non-metastasizing malignancy (Table VIB). There were 5 instances, however, with serum phosphatase activity less than 5 Bodansky units, despite definite metastatic involvement of the liver; and Case 320 presented both hepatic and skeletal (osteolytic) metastases without any significant rise in serum phosphatase activity (an exceptional occurrence in our experience). The patients with little or no elevation in serum phosphatase level were not icteric.

In general, the serum phosphatase activity tends to be higher in patients with diffuse spread of large nodules throughout the liver. Our highest values were in patients who showed jaundice, though some were only slightly icteric (Cases 301, $302)$; and in several instances the serum phos- 
TABLE VI

Summary of analyses of the blood in four proven cases of primary carcinoma of the liver; ten cases of malignancy without liver metastases; and twenty-two cases of malignancy with proven involvement of the liver

\begin{tabular}{|c|c|c|c|c|c|c|}
\hline \multirow{2}{*}{$\underset{\text { ber }}{\text { Num- }}$} & \multirow{2}{*}{ Sex } & \multirow{2}{*}{ Age } & \multirow{2}{*}{ Primary tumor; basis for diagnosis } & \multicolumn{2}{|c|}{ Serum } & \multirow{2}{*}{ Remarks } \\
\hline & & & & $\begin{array}{l}\text { Phos- } \\
\text { phatase }\end{array}$ & $\begin{array}{l}\text { Bili- } \\
\text { rubin }\end{array}$ & \\
\hline & & years & . & $\begin{array}{c}\text { Bodansky } \\
\text { units per } \\
100 \text { cc. }\end{array}$ & $\begin{array}{c}\text { mgm. } \\
\text { per } \\
100 \\
c c .\end{array}$ & \\
\hline
\end{tabular}

A. PRIMARY CARCINOMA OF THE LIVER

\begin{tabular}{|c|c|c|c|c|c|c|}
\hline 287 & q & 41 & Cholangioma (autopsy) & $\begin{array}{l}25.8 \\
33.1 \\
29.7\end{array}$ & $\begin{array}{l}4.7 \\
4.4 \\
3.2\end{array}$ & $\begin{array}{l}\text { April } 20,1938 \\
\text { May } 9,1938 \\
\text { June } 1,1938\end{array}$ \\
\hline 288 & $\sigma^{7}$ & 65 & Hepatoma, cirrhosis (liver biopsy) & 16.8 & 4.0 & January 6,1938 \\
\hline $\begin{array}{l}289 \\
290\end{array}$ & $\begin{array}{l}\sigma^{7} \\
\text { क }\end{array}$ & $\begin{array}{l}38 \\
57\end{array}$ & $\begin{array}{l}\text { Hepatoma, cirrhosis (liver biopsy) } \\
\text { Cholangioma (autopsy) }\end{array}$ & $\begin{array}{l}21.4 \\
16.3 \\
11.5\end{array}$ & $\begin{array}{l}3.0 \\
2.5\end{array}$ & $\begin{array}{l}\text { June } 1,1939 \\
\text { June } 29,1937\end{array}$ \\
\hline
\end{tabular}

B. MalignanCy Without LIVER METASTASES

\begin{tabular}{l|l|l|l|r|r|l}
\hline 291 & $\sigma^{7}$ & 67 & Carcinoma of prostate gland (autopsy) & 44.4 & 0 & Extensive osteoplastic metastases to bone. \\
292 & $\sigma^{7}$ & 61 & Carcinoma of prostate gland (autopsy) & 21.6 & 0 & Extensive osteoplastic metastases to bone. \\
293 & + & 43 & Melanosarcoma (autopsy) & 7.8 & trace & Brain metastases; focal necroses of liver. \\
& & & & 3.9 & 0 & \\
294 & $\sigma^{7}$ & 57 & Carcinoma of colon (autopsy) & 7.4 & 0 & Large local abscess formation. \\
295 & $\sigma^{7}$ & 71 & Carcinoma of stomach (autopsy) & 4.9 & 1.0 & Local metastases to nodes. \\
296 & + & 60 & Carcinoma of lung (autopsy) & 4.5 & 0 & Metastases to lung, lymph nodes. \\
297 & $\sigma^{7}$ & 55 & Oat cell tumor of lung (autopsy) & 4.1 & 0 & Metastases to brain, adrenals, etc. \\
298 & $\$$ & 47 & Lymphosarcoma (autopsy) & 3.9 & 0 & Metastases to spleen, pelvis. \\
299 & $\sigma^{7}$ & 70 & Carcinoma of colon (autopsy) & 3.4 & 0 & No metastases. \\
300 & + & 70 & Lymphosarcoma (autopsy) & 3.2 & 0 & Metastases to lung, skin, spleen, etc. \\
\hline
\end{tabular}

C. MALignaNCy With LIVER MEtastases

\begin{tabular}{|c|c|c|c|c|c|c|}
\hline $\begin{array}{l}301 \\
302 \\
303 \\
304 \\
305 \\
306 \\
307\end{array}$ & 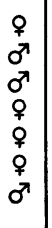 & $\begin{array}{l}43 \\
39 \\
32 \\
63 \\
36 \\
82 \\
74\end{array}$ & $\begin{array}{l}\text { Primary not known (liver biopsy) } \\
\text { Carcinoma of esophagus (autopsy) } \\
\text { Reticulum cell sarcoma (autopsy) } \\
\text { Carcinoma of colon (liver biopsy) } \\
\text { Carcinoma of stomach (autopsy) } \\
\text { Carcinoma of tail of pancreas (autopsy) } \\
\text { Primary not known (autopsy) }\end{array}$ & $\begin{array}{l}23.9 \\
21.5 \\
20.7 \\
19.8 \\
18.8 \\
18.3 \\
13.1\end{array}$ & $\begin{array}{c}2.5 \\
2.7 \\
5.0 \\
9.6 \\
\text { trace } \\
0 \\
7.4\end{array}$ & $\begin{array}{l}\text { Many liver metastases; jaundiced } 1 \text { year. } \\
\text { Many liver metastases. } \\
\text { Many liver metastases. } \\
\text { Many liver metastases; jaundiced } 1 \text { month. } \\
\text { Many liver metastases. } \\
\text { Many liver metastases. } \\
\text { Many liver metastases; duration of jaundice not } \\
\text { known. }\end{array}$ \\
\hline $\begin{array}{l}308 \\
309 \\
310\end{array}$ & $\begin{array}{l}\sigma^{7} \\
\sigma^{7} \\
\sigma^{7}\end{array}$ & $\begin{array}{l}47 \\
60 \\
60\end{array}$ & $\begin{array}{l}\text { Primary not known (celiotomy) } \\
\text { Carcinoma of bronchus (autopsy) } \\
\text { Sarcoma? of testis (autopsy) }\end{array}$ & $\begin{array}{r}12.3 \\
10.4 \\
9.7\end{array}$ & $\begin{array}{c}0.5 \\
2.7 \\
\text { trace }\end{array}$ & $\begin{array}{l}\text { Many liver metastases. } \\
\text { Many liver metastases. } \\
\text { Diffuse microscopic infiltration of liver; no gross }\end{array}$ \\
\hline 311 & \% & 52 & Melanosarcoma (!iver biopsy) & 9.0 & 8.3 & $\begin{array}{l}\text { nodules. } \\
\text { Many liver metastases. Duration of jaundice }\end{array}$ \\
\hline $\begin{array}{l}312 \\
313\end{array}$ & $\begin{array}{l}\sigma^{7} \\
\sigma^{7}\end{array}$ & $\begin{array}{l}63 \\
69\end{array}$ & $\begin{array}{l}\text { Carcinoma of kidney (autopsy) } \\
\text { Carcinoma of prostate gland (autopsy) }\end{array}$ & $\begin{array}{l}8.5 \\
8.4\end{array}$ & $\begin{array}{l}\mathbf{0} \\
\mathbf{0}\end{array}$ & $\begin{array}{l}\text { Many liver metastases. (Early bone invasion, } \\
\text { Many liver metastases. (Early } \\
\text { osteolytic). }\end{array}$ \\
\hline $\begin{array}{l}314 \\
315\end{array}$ & $\begin{array}{l}\text { } \\
\wp\end{array}$ & $\begin{array}{l}51 \\
40\end{array}$ & $\begin{array}{l}\text { Carcinoma of cervix (autopsy) } \\
\text { Krukenberg tumor (autopsy) }\end{array}$ & $\begin{array}{l}7.5 \\
6.7\end{array}$ & $\begin{array}{c}0 \\
\text { trace }\end{array}$ & $\begin{array}{l}\text { Many liver metastases. } \\
\text { Many liver metastases; extensive osteolytic } \\
\text { bone metastases. }\end{array}$ \\
\hline $\begin{array}{l}316 \\
317 \\
318 \\
319 \\
320\end{array}$ & $\begin{array}{l}o \\
\sigma^{7} \\
\sigma^{7} \\
\$ \\
\sigma^{7}\end{array}$ & $\begin{array}{l}35 \\
54 \\
62 \\
63 \\
50\end{array}$ & $\begin{array}{l}\text { Carcinoma of rectum (liver biopsy) } \\
\text { Carcinoma of stomach (autopsy) } \\
\text { Primary not known (liver biopsy) } \\
\text { Carcinoma of colon (autopsy) } \\
\text { Oat cell tumor of lung (autopsy) }\end{array}$ & $\begin{array}{l}6.5 \\
6.3 \\
4.9 \\
4.4 \\
4.2\end{array}$ & $\begin{array}{c}\text { trace } \\
0 \\
\text { trace } \\
0 \\
0\end{array}$ & $\begin{array}{l}\text { Many liver metastases. } \\
\text { Slight infiltration of liver. } \\
\text { Many liver metastases. } \\
\text { Many liver metastases. } \\
\text { Few liver metastases; extensive osteolytic bone } \\
\text { infiltration. }\end{array}$ \\
\hline $\begin{array}{l}321 \\
322\end{array}$ & $\begin{array}{l}\sigma^{7} \\
\sigma^{7}\end{array}$ & $\begin{array}{l}56 \\
63\end{array}$ & $\begin{array}{l}\text { Hodgkin's sarcoma (autopsy) } \\
\text { Carcinoma of colon (autopsy) }\end{array}$ & $\begin{array}{l}4.1 \\
4.0\end{array}$ & $\begin{array}{c}0 \\
\text { trace }\end{array}$ & $\begin{array}{l}\text { Several liver metastases. } \\
\text { One nodule in liver. }\end{array}$ \\
\hline
\end{tabular}


phatase level was distinctly increased before jaundice developed (Cases 305, 306; 308). It has been our experience that significantly increased serum phosphatase activity occurs more consistently in this group of patients than does hyperbilirubinemia. Some of the most striking examples of this are not included in Table VI because, though the diagnosis of malignancy with liver metastases was obvious clinically, permission for autopsy and proof of the diagnosis could not be obtained.

\section{Liver abscess; chronic passive congestion of the} liver; miscellaneous disorders of the liver;

cases of gall bladder disease with in-

determinate effect upon the patency of the common bile duct

Table VIIA includes 9 cases of liver abscess of diverse etiology. The diagnosis was estab- lished by exploration or necropsy except in 2 patients with amebic abscess in whom the diagnosis would seem beyond reasonable doubt on clinical and laboratory grounds. The serum phosphatase activity was variable but definitely increased in every instance, ranging from 7.9 to 49.4 Bodansky units per $100 \mathrm{cc}$. The highest serum phosphatase levels occurred in jaundiced patients.

Table VIIB includes 10 patients with marked chronic passive congestion of the liver in decompensated cardiacs of long standing who at necropsy were found to have little or no "cardiac" cirrhosis. Congestive failure may cause some increase in serum phosphatase activity, particularly in patients who develop clinically demonstrable jaundice; 2 such patients in our series (Cases 332 and 333) reaching levels of 8.6 Bodansky units per $100 \mathrm{cc}$. In 4 instances, the values were within normal limits despite the presence of marked congestive hepatomegaly.

TABLE VII

Summary of analyses of the blood in nine cases of liver abscess; ten cases of chronic passive congestion of the liver; eight cases of miscellaneous disorders of the liver; and nine cases of gall bladder disease with indeterminate effect upon the patency of the common bile duct

\begin{tabular}{|c|c|c|c|c|c|c|c|}
\hline \multirow{2}{*}{ Number } & \multirow{2}{*}{ Sex } & \multirow{2}{*}{ Age } & \multirow{2}{*}{ Diagnosis } & \multirow{2}{*}{ Date } & \multicolumn{2}{|c|}{ Serum } & \multirow{2}{*}{ Remarks } \\
\hline & & & & & $\begin{array}{c}\text { Phos- } \\
\text { phatase }\end{array}$ & $\begin{array}{l}\text { Bili- } \\
\text { rubin }\end{array}$ & \\
\hline & & years & & & $\begin{array}{l}\text { Bodansky } \\
\text { units per } \\
100 \text { cc. }\end{array}$ & $\begin{array}{l}\underset{\text { mgm }}{\text { per } 100} \\
\text { cc. }\end{array}$ & \\
\hline
\end{tabular}

A. LIVER ABSCESS

\begin{tabular}{|c|c|c|c|c|c|c|c|}
\hline 323 & $\sigma^{x}$ & 59 & Ruptured viscus? (operation) & May 29, 1939 & 42.1 & 4.0 & Sub- and intrahepatic abscess at hilum. Jaun- \\
\hline 324 & $\sigma^{7}$ & 21 & Miliary tuberculosis (autopsy) & July 26,1938 & 26.6 & 4.7 & Disseminated tubercular abscesses of liver. \\
\hline 326 & \& & 52 & Post-operative infection (opera- & $\begin{array}{l}\text { August } 9,1938 \\
\text { September 22, } 1937 \\
\text { November 16, } 1937 \\
\text { December } 9,1937 \\
\text { December } 20,1937 \\
\text { November } 23,1938\end{array}$ & $\begin{array}{l}18.0 \\
15.2 \\
49.4 \\
39.6 \\
34.5 \\
14.0\end{array}$ & $\begin{array}{r}11.5 \\
7.0 \\
3.5 \\
2.9 \\
0\end{array}$ & $\begin{array}{l}\text { Jaundiced one week. } \\
\text { Large hilar abscess obstructing main hepatic } \\
\text { ducts. Jaundiced two years, intermittently. } \\
\text { Multiple liver abscesses. }\end{array}$ \\
\hline 327 & \& & 26 & $\begin{array}{l}\text { tion) } \\
\text { Tularemia ? (autopsy) }\end{array}$ & $\begin{array}{l}\text { October 13, } 1937 \\
\text { October 22, } 1937\end{array}$ & 13.4 & trace & Multiple intra- and subhepatic abscesses. \\
\hline 328 & ه & 32 & $\begin{array}{l}\text { Multiple liver abscesses (opera- } \\
\text { tion) }\end{array}$ & $\begin{array}{l}\text { January } 10,1938 \\
\text { December } 11,1937 \\
\text { December } 28,1937\end{array}$ & $\begin{aligned} 19.1 \\
10.3 \\
7.2\end{aligned}$ & $\begin{array}{l}3.9 \\
\mathbf{3 . 0} \\
\mathbf{3 . 0}\end{array}$ & Following empyema of gall bladder. \\
\hline 329 & $\sigma^{7}$ & 70 & Amebic abscess (clinical) & November 1,1937 & 9.5 & 2.1 & Amebic cysts in stool, fever, etc. \\
\hline $\begin{array}{l}330 \\
331\end{array}$ & कृ & $\begin{array}{l}26 \\
44\end{array}$ & $\begin{array}{l}\text { Amebic abscess (operation) } \\
\text { Amebic abscess (clinical) }\end{array}$ & $\begin{array}{l}\text { January } 19,1939 \\
\text { May } 17,1939 \\
\text { January } 28,1938\end{array}$ & $\begin{array}{l}8 . \\
8 .\end{array}$ & $\begin{array}{r}0 \\
2.0 \\
0\end{array}$ & $\begin{array}{l}\text { Recurrence. } \\
\text { Recurrence. } \\
\text { Amebae in stool; fever, etc. }\end{array}$ \\
\hline
\end{tabular}

B. Chronic PASSIVE CONGESTION OF THE LIVER

(Autopsy diagnoses in every instance)

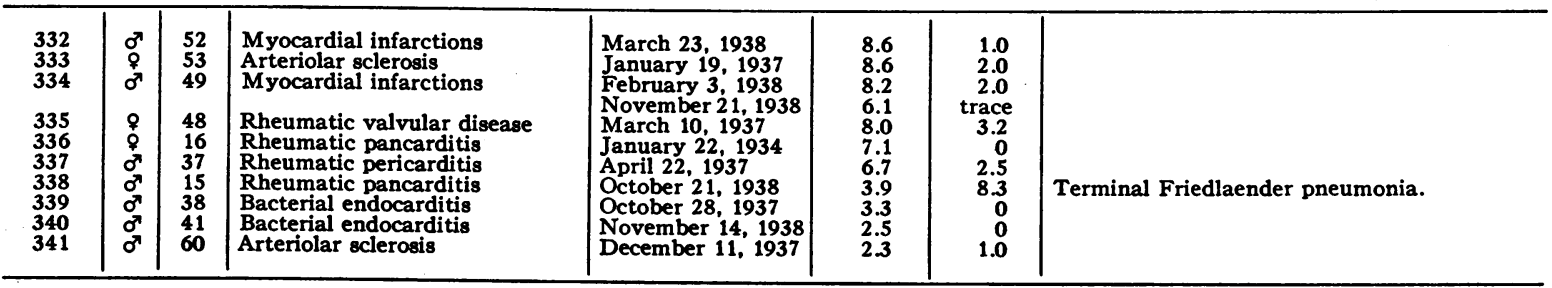


TABLE VII-Continued

\begin{tabular}{|c|c|c|c|c|c|c|c|}
\hline \multirow{2}{*}{ Number } & \multirow{2}{*}{ Sex } & \multirow{2}{*}{ Age } & \multirow{2}{*}{ Diagnosis } & \multirow{2}{*}{ Date } & \multicolumn{2}{|c|}{ Serum } & \multirow{2}{*}{ Remarks } \\
\hline & & & & & $\begin{array}{l}\text { Phos- } \\
\text { phatase }\end{array}$ & $\begin{array}{c}\text { Bill- } \\
\text { rubin }\end{array}$ & \\
\hline & & years & & & $\begin{array}{l}\text { Bodansky } \\
\text { units per } \\
100 \text { cc. }\end{array}$ & $\begin{array}{l}\text { mgm. } \\
\text { per } 100 \\
\text { cc. }\end{array}$ & \\
\hline
\end{tabular}

C. MISCELLANEOUS DISORDERS OF THE LIVER

\begin{tabular}{|c|c|c|c|c|c|c|c|}
\hline 342 & \& & 75 & Stone in common duct (opera- & June 18,1938 & 20.0 & 2.0 & Localized Paget's disease, pelvis. \\
\hline 343 & ब & 64 & Stone in common duct (opera- & March 5, 1935 & 17.9 & 3.0 & Localized Paget's disease, pelvis. \\
\hline 344 & $\sigma^{7}$ & 48 & Pneumonia, septicemia & January 6, 1937 & 4.8 & 9.0 & Complicated by jaundice. \\
\hline 346 & $\sigma^{7}$ & $\begin{array}{l}26 \\
70\end{array}$ & $\begin{array}{l}\text { Pneumonia (clinical) } \\
\text { Pneumonia, empyema, uremia }\end{array}$ & $\begin{array}{l}\text { March } 26,1937 \\
\text { April 2, } 1937 \\
\text { April 13, } 1937 \\
\text { January } 18,1937 \\
\text { February } 8,1937\end{array}$ & $\begin{array}{r}1.7 \\
5.0 \\
4.0 \\
7.7 \\
12.9\end{array}$ & $\begin{array}{l}2.8 \\
2.0 \\
0 \\
6.9 \\
1.0\end{array}$ & $\begin{array}{l}\text { Complicated by jaundice. } \\
\text { Complicated by jaundice. }\end{array}$ \\
\hline 347 & 8 & 58 & Tuberculosis of liver (liver & $\begin{array}{l}\text { February 10, } 1937 \\
\text { January 28, } 1939\end{array}$ & $\begin{array}{l}22.4 \\
14.4\end{array}$ & $\begin{array}{l}1.0 \\
2.0\end{array}$ & Extensive infiltration. \\
\hline 348 & $\stackrel{\sigma^{7}}{q}$ & $\begin{array}{l}35 \\
28\end{array}$ & $\begin{array}{l}\text { Dodgkin's disease (autopsy) } \\
\text { Echinococcus cyst of liver } \\
\text { (operation) }\end{array}$ & $\begin{array}{l}\text { June } 9,1936 \\
\text { September 6, } 1938 \\
\text { March 17, } 1939\end{array}$ & $\begin{array}{l}7.3 \\
4.6 \\
4.5\end{array}$ & $\begin{array}{r}9.0 \\
\text { trace } \\
\text { trace }\end{array}$ & $\begin{array}{l}\text { Extensive infiltration of portal areas. } \\
\text { Left lobe of liver involved. }\end{array}$ \\
\hline \multicolumn{8}{|c|}{ D. Chronic gall bLadder disease } \\
\hline 350 & \& & 54 & Cholelithiasis (operation) & $\begin{array}{l}\text { October } 30,1937 \\
\text { November } 13,1937 \\
\text { November } 12,1937\end{array}$ & $\begin{array}{r}19.6 \\
10.0 \\
7.5\end{array}$ & $\begin{array}{r}15.0 \\
9.0 \\
2.9\end{array}$ & $\begin{array}{l}\text { Operation December } 7,1937 \text {, no stone in com- } \\
\text { mon duct. }\end{array}$ \\
\hline 351 & \& & 63 & Cholelithiasis (operation) & May 25, 1937 & 18.0 & 6.0 & Operation June 8,1937 , no stone in common \\
\hline 352 & \& & 50 & Cholelithiasis (operation) & March 6, 1938 & 11.9 & 6.0 & Operation March 14, 1938, no stone in common \\
\hline 353 & ? & 40 & Cholelithiasis (operation) & September 29, 1938 & 7.3 & 7.5 & Operation October 4,1938, no stone in common \\
\hline 354 & q & 19 & Cholelithiasis (operation) & October 2, 1936 & 3.0 & 8.3 & Operation October 14, 1936, no stone in com- \\
\hline 355 & \% & 61 & Cholelithiasis (operation) & March 13, 1936 & 3.6 & trace & Operation March 16, 1936, no stone in common \\
\hline 356 & $\sigma^{\pi}$ & 56 & Cholelithiasis (operation) & March 20, 1939 & 4.4 & trace & Operation March 25, 1938, no stone in common \\
\hline 357 & q & 59 & Cholelithiasis (operation) & May 26, 1939 & 3.6 & $\mathbf{0}$ & Operation June 6,1939 , no stone in common \\
\hline 358 & $\sigma^{\pi}$ & 30 & Cholelithiasis (operation) & $\begin{array}{l}\text { March 7, } 1939 \\
\text { March 13, } 1939 \\
\text { March 20, } 1939 \\
\text { March 29, } 1939 \\
\text { April 10, } 1939\end{array}$ & $\begin{array}{l}6.5 \\
5.7 \\
2.3 \\
7.2 \\
5.4\end{array}$ & $\begin{array}{r}6.2 \\
11.5 \\
17.0 \\
6.3 \\
2.7\end{array}$ & $\begin{array}{l}\text { Opuct. } \\
\text { duct; spasm of sphincter of Oddi? }\end{array}$ \\
\hline
\end{tabular}

Eight patients with miscellaneous types of hepatic disease are included in Table VIIC. Cases 342 and 343 illustrate difficulties in the application of the serum phosphatase determination to the differential diagnosis of jaundice in patients with bone disease. In both instances a marked increase in serum phosphatase activity, with slight jaundice, was noted but was not interpretable because Paget's disease was present (localized lesions not apparent clinically but disclosed incidentally by $\mathbf{x}$-rays). These patients subsequently proved to have stone in the common duct. In a previously recorded instance (Case 116) confusingly high serum phosphatase values due to clinically unrecognizable Paget's disease were obtained in a case of hepatitis.

Jaundice developing in patients with pneumonia (" toxic" or " infective" jaundice) usually is as- sociated with comparatively little increase in serum phosphatase activity, as shown in Cases 344 and 345. In Case 346, whose course was complicated by empyema, there was a terminal rise in the serum phosphatase activity to 22.4 Bodansky units per $100 \mathrm{cc}$., a level we have not encountered otherwise in this type of case. There was no adequate explanation for this increase at autopsy, which disclosed only focal necroses of the liver. Case 347, with serum phosphatase of 14.4 Bodansky units, was found to have tubercles extensively involving the liver. Case 348 had Hodgkin's disease of the liver, confined to the portal areas. Case 349 is of interest because a very large echinococcus cyst was present but did not effect a significant rise in serum phosphatase activity. The cyst involved the left lobe of the liver, which may have some bearing on the result. 
Table VIID comprises 9 cases of gall bladder disease with jaundice, a large and important clinical group but one which presents many difficulties in classification. Several investigators in this field have regarded all such cases as jaundice due to obstruction of the common bile duct, irrespective of whether or not operation disclosed a stone in the common duct; apparently on the assumption that mechanical obstruction or sphincter spasm are the sole causes of jaundice under these circumstances. So far as evaluation of the serum phosphatase determination is concerned, we have preferred to classify as obstructive jaundice only those cases of biliary tract disease in which mechanical obstruction of the common bile duct could be demonstrated at operation or autopsy. Patients in whom no such obstruction was found have been regarded for the present purpose as unclassifiable and were omitted from our statistical series. In some of our patients in this category (Cases 350, 351, and 352), serum phosphatase values over 10 Bodansky units were associated with definite hyperbilirubinemia and typical biliary colic suggesting stone in the common bile duct; there was spontaneous cessation of pain and rapid subsidence of jaundice, and operation about 1 week thereafter disclosed cholelithiasis but no stone in or dilatation of the common duct. This sequence of events is consistent with spontaneous passage of a stone in the common duct but proof is wanting. In other instances (Cases 353 and 354), the clinical course and the operative findings were the same, definite jaundice was present but the serum phosphatase level showed little or no increase. It is impossible to say whether a stone occluded the common duct at the time the patient was icteric and the serum phosphatase failed to rise to its usual level; or whether the jaundice was caused by transitory infection of the biliary tract or hepatitis. Even more difficult of interpretation are instances in which the first serum phosphatase determination was made after jaundice had subsided spontaneously (Case 355), conditions under which the method is without value. Cases 356 and 357 illustrate essentially normal serum phosphatase values characteristic of chronic gall bladder disease uncomplicated by jaundice.

Another source of error inherent in our classification of obstruction of the extrahepatic biliary tract on the basis of mechanical occlusion lies in the possible inadvertent exclusion of obstruction due to spasm of the sphincter of Oddi. In those instances in which this mechanism was suggested at operation as the cause of icterus, it was not possible to obtain convincing objective proof of the causal relation of spasm to jaundice. For example, Case 358 was found to have cholecystitis and cholelithiasis but no stone in or dilatation of the common bile duct at operation (at which time the serum bilirubin was markedly elevated but the serum phosphatase activity insignificantly increased). Cholangiograms showed some narrowing of the distal end of the common duct, without delay in emptying. Liver biopsy was variously interpreted as hepatitis or essentially normal liver but was not thought to suggest obstructive jaundice. Manometer readings of bile duct pressure after injection of saline into the drainage tube gave equivocal results. The jaundice increased after operation, then slowly subsided.

\section{ANALYSIS AND DISCUSSION OF TOTAL SERIES OF OBSERVATIONS 1933 TO 1939}

\section{Distribution of serum phosphatase values in major diseases of the liver and biliary tract}

Perhaps the clearest summary of our results is afforded by an analysis of their distribution in certain common disorders of the liver and biliary tract. The total number of such cases available for analysis is 308 , the several categories of dissease considered and their respective representation being indicated in Table VIII. For reasons stated elsewhere, observations in children are excluded. Only the initial values obtained in each patient were employed for purposes of analysis, but an exception was made in Case 246 for reasons evident in the text. Patients with biliary cirrhosis (including Case 73 (1)) are classified according to the type of biliary tract obstruction and do not appear in the cirrhosis group.

Of a total of 34 patients with jaundice due to stone obstructing the common bile duct, 5 or roughly 15 per cent had serum phosphatase levels less than 10 Bodansky units per $100 \mathrm{cc}$; as did 2 or roughly 5 per cent of 45 patients with noncalculous common bile duct obstruction (chiefly carcinoma of the head of the pancreas). Consid- 
TABLE VIII

Distribution of serum phosphatase values in major disorders of the liver and biliary tract: analysis of results in 308 adults (initial values only)

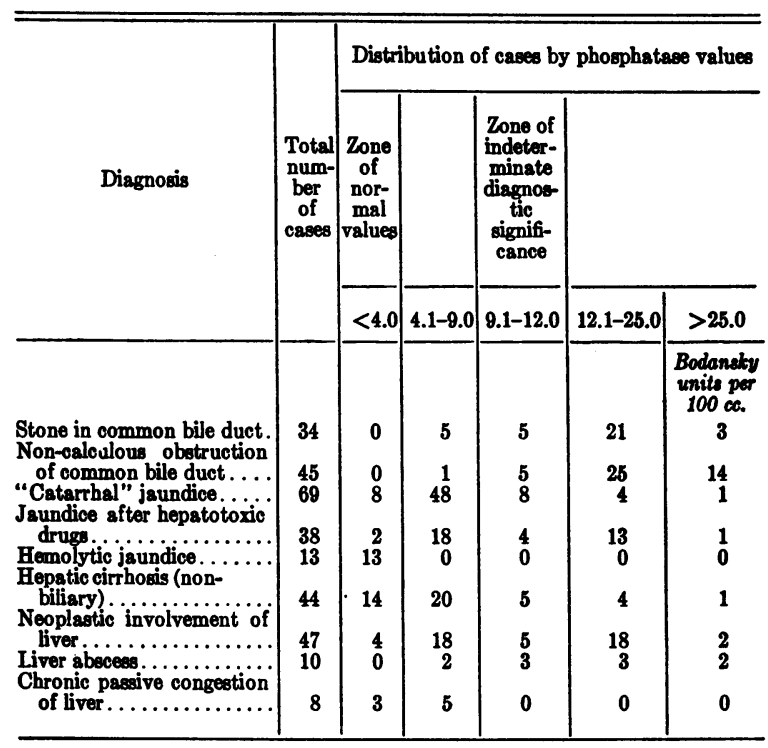

ering the 79 cases of proven obstructive jaundice as a whole, about 10 per cent failed to show phosphatase levels over 10 Bodansky units per $100 \mathrm{cc}$. serum. Of a total of 107 cases classified as "hepatitis," 82 or roughly 75 per cent had serum phosphatase levels less than 10 Bodansky units per $100 \mathrm{cc}$. If, as we have proposed, patients with jaundice following exposure to hepatotoxic agents be excluded from the heterogeneous "hepatitis" group, then 62 of the 69 remaining cases (90 per cent) had serum phosphatase levels less than 10 Bodansky units per $100 \mathrm{cc}$.

There would seem to be little point in further pursuing the analysis along these lines because, in practice, many values that are slightly above or below 10 Bodansky units are of indeterminate diagnostic significance. This difficulty is recognized in the distribution of values as summarized in Table VIII, which gives a more representative picture of the applicability of the serum phosphatase determination in our hands. It will be noted that 6 of 79 patients with proven common duct obstruction had serum phosphatase levels not exceeding 9.0 Bodansky units per $100 \mathrm{cc}$., 5 being instances of choledocholithiasis with incomplete or intermittent occlusion. The values in 10 patients of this group further fell into the indeterminate zone of 9.1 to 12.0 Bodansky units.
Sixty-three or 80 per cent of the total number of cases with jaundice due to gross common duct obstruction showed serum phosphatase values over 12.0 Bodansky units per 100 cc. Values over 25 Bodansky units were obtained usually but not invariably in patients with complete and protracted obstruction of the common bile duct due to neoplasm.

In " catarrhal " jaundice, on the other hand, 56 of 69 cases (about 80 per cent) had serum phosphatase levels less than 9.0 Bodansky units per 100 cc., 8 were at indeterminate levels and 5 (about 7 per cent) exceeded 12.0 Bodansky units. When the relation of serum phosphatase to serum bilirubin levels in these two major types of jaundice is taken into consideration, the differences between them become even more striking. Those patients with obstructive jaundice who showed little increase in serum phosphatase activity had relatively slight hyperbilirubinemia, as obstruction was incomplete; whereas even marked jaundice of hepatogenous origin was associated for the most part with comparatively little elevation in serum phosphatase activity.

The distribution of serum phosphatase values in hemolytic jaundice and in chronic passive congestion of the liver is limited to the normal range or slightly above, as already indicated. In patients with liver abscess the values are preponderantly in the range of obstructive jaundice or fall within the zone of indeterminate significance. Thirty-four of 44 cases (about 75 per cent) of cirrhosis other than biliary cirrhosis had serum phosphatase levels less than 9.0 Bodansky units per $100 \mathrm{cc}$., and 5 fell within the indeterminate zone.

The distribution of serum phosphatase values in two categories of liver disease deserves special comment because a double peak in the incidence curve appears, one within the "hepatitis" zone, the other in the zone of obstructive jaundice. These are the group with jaundice due to hepatotoxic drugs and the series comprising patients with neoplastic involvement of the liver. In the former, as already indicated, there is some evidence that two distinct types of jaundice may be present. In the latter group, the spread in serum phosphatase values appears to relate to the number and distribution of metastases in the liver. 
2. Clinical usefulness and limitations of the determination of serum phosphatase activity as applied to diseases of the liver and biliary tract

A. Evaluation of the method as a supplementary aid to the clinical differentiation of the several types of jaundice. The chief usefulness of the determination of serum phosphatase activity derives, we believe, from the consistency with which distinctly increased values accompany obstruction of the extrahepatic biliary tract. We have found it helpful to recognize that jaundice in patients with serum phosphatase levels less than 10 Bodansky units per $100 \mathrm{cc}$. is probably not due to gross obstruction of the common bile duct. When exploration was contemplated in such patients, it proved good policy to observe the patient further until additional clinical and laboratory data could be obtained.

While the absence of significantly increased serum phosphatase activity in icteric patients is valid evidence against obstruction of the common bile duct, in our experience, it does not follow that a serum phosphatase value greater than 10 Bodansky units accompanying jaundice automatically marks the patient for exploration. The finding of a serum phosphatase level exceeding 10 Bodansky units per $100 \mathrm{cc}$. in icteric patients, to be sure, is consistent with the clinical diagnosis of obstructive jaundice. But in addition to obstruction of the extrahepatic biliary tract warranting surgical intervention, marked elevations in serum phosphatase activity also occur frequently in arsphenamine jaundice and with liver metastases, occasionally in hepatitis and other liver diseases requiring conservative management, and in a variety of skeletal disorders. It was sometimes but not always possible for us to exclude these further possibilities by careful history-taking and appropriate roentgenographic and clinical studies.

To indicate what seems to us to be a particular advantage of the serum phosphatase determination in the differential diagnosis of jaundice requires a consideration of certain difficulties inherent in the clinical application of any physiological aid to the diagnosis of liver disease. As pointed out by several investigators $(8,9)$, the simple but arbitrary division of clinical jaundice into three discrete categories, obstructive, hepato- genous and hemolytic, however convenient clinically, does not adequately define the mechanisms actually operating in many patients. The initial or predominant cause of jaundice may fall into one or another of these distinct categories, but serious disturbance of one mechanism soon involves others and this complexity is reflected in equivocal or confusing results with the test employed. The disadvantage of most liver function tests used in the differential diagnosis of jaundice lies in the circumstance that they provide only negative evidence for obstruction; that is, mechanical obstruction of the common bile duct is suggested by the absence of any significant alteration in a given function of the liver in patients with jaundice. While this often suffices, if significant liver parenchymal injury complicates obstruction (as with cholangeitis or biliary cirrhosis developing in protracted obstructive jaundice) then the negative effect of obstruction may be superseded by the positive effects of secondary inflammatory or degenerative changes. Under these circumstances, liver function tests not infrequently give equivocal or confusing results and the possibility of error is not minimized by a multiplicity of such tests all having much the same limitation.

It would seem desirable rather to complement the liver function tests with some positive measure of biliary tract obstruction. We find the determination of serum phosphatase activity satisfactory for this purpose, since inflammatory or cirrhotic changes secondary to common bile duct obstruction do not ordinarily significantly lower the phosphatase level of the serum. Other positive indices of biliary tract obstruction, such as the total cholesterol content of the serum, have proved less consistently helpful in our hands (Table I), particularly in the clinically important group of patients with incomplete mechanical obstruction of the common bile duct. The range of variation in the serum cholesterol content of different normal subjects, moreover, is extremely broad so that interpretation of values in any one case of jaundice may be difficult; whereas we find the range of variation in serum phosphatase activity in the normal adult relatively narrow and the many-fold increase encountered in obstructive jaundice facilitates interpretation of results.

There are further minor advantages that recommend the serum phosphatase determination for 
test purposes in jaundiced patients: it does not require the administration of substances that may or may not be innocuous to the disordered liver; and it is not significantly affected by renal disease, in our experience.

As to the disadvantages of the method, there are several that limit its applicability in the differentiation of the several types of jaundice. The foremost of these is overlapping of serum phosphatase values in the obstructive and hepatogenous groups of jaundiced patients. The degree of overlapping noted by different investigators has varied extraordinarily, some finding it so large as to disqualify the method for differential diagnosis ( $3 \mathrm{~b}, 3 \mathrm{f})$, others finding the overlapping of values sufficient to limit but not invalidate the usefulness of the determination $(3 \mathrm{c}, 3 \mathrm{~h})$. There is general though not unanimous agreement, however, regarding the relative consistency of distinctly increased serum phosphatase levels in jaundice due to obstruction of the common bile duct. As suggested elsewhere (1), these discrepancies in experience may be ascribable, in part, to variations in technique of the serum phosphatase determination, in the classification of clinical material, or in the adequacy of evidence adduced for the classification of cases.

The differentiation of obstructive from hepatogenous jaundice is further confused by overlapping of serum phosphatase values obtained in other diseases of the liver and biliary tract, as shown in our tables. Consequently, we feel that the chief usefulness of the determination in the differential diagnosis of jaundice is in excluding, with high probability, obstruction of the common bile duct as a cause of jaundice in patients showing no marked increase in serum phosphatase activity.

Another difficulty with the serum phosphatase determination as applied to the differential diagnosis of jaundice lies in its lack of specificity. As is well known $(10,11,12,13)$, the phosphatase activity of the serum is increased in a variety of skeletal disorders, notably Paget's disease, rickets, carcinoma with bone metastases, particularly of the osteoplastic type, hyperparathyroidism and osteogenic sarcoma. The serum phosphatase level cannot be applied to the diagnosis of disease of the liver or biliary tract in patients presenting any of these bone conditions. Ordinarily, apprecia- tion of this limitation avoids confusion because the skeletal disorder is readily recognizable. But errors occur occasionally when localized Paget's disease or metastatic bone involvement, discoverable only by appropriate $\mathrm{x}$-rays, is overlooked. Apart from these skeletal disorders, no other conditions significantly affect the serum phosphatase level consistently enough to interfere seriously with the use of the method in jaundice, so far as we could discover. If skeletal disease can be ruled out, it has been our experience that patients with definitely elevated serum phosphatase level, whether jaundiced or not, generally prove to have one or another type of liver disease.

Further difficulties with the serum phosphatase determination are encountered when it is applied to the differential diagnosis of jaundice in children. The method appears to be of no value in an important problem of this kind in infants: the differentiation of congenital atresia of the bile ducts from " physiological jaundice." Throughout the period of skeletal growth, the range of normal variation in serum phosphatase activity is so broad and ill-defined (roughly 4 to 12 or more Bodansky units per $100 \mathrm{cc}$.), that the values obtained in hepatitis in children are confusingly high $(3 a, 3 g)$. Although our experience with this age period has been limited, we feel that for the present the method is not applicable to growing children.

Finally, as already indicated, we find the serum phosphatase determination of little value in the diagnosis of Laënnec's cirrhosis and of largely academic interest in hemolytic jaundice.

$B$. The determination of serum phosphatase activity as an aid in the diagnosis of complications following surgery of the biliary tract. In all, 24 patients with obstructive jaundice were studied both before and after attempted relief of common duct obstruction by surgical measures. Because of the complexities involved, our data are too incomplete for any but the most general inferences, and in 3 patients are wholly inadequate for analysis.

Decompression by establishment of external or internal biliary fistulae in obstructive jaundice, if successful in effecting adequate drainage and if not complicated by infection, resulted in a roughly parallel fall in both serum bilirubin and phosphatase levels (Cases 5, 11, 18, 21, 23, 125, 128, 151, 
155). The post-operative course under these circumstances was usually uneventful. When exploration disclosed that obstruction of the common bile duct was due to carcinoma so extensive as to discourage any attempt at drainage, or when an unsuccessful attempt at drainage was made, both serum bilirubin and phosphatase showed a parallel tendency to remain elevated or to rise further (Cases 2, 22, 168).

In many patients both serum bilirubin and serum phosphatase levels fell following establishment of biliary drainage but a secondary rise in serum phosphatase activity was noted, not necessarily associated with a comparable rise in serum bilirubin. Meranze, Meranze and Rothman ( $3 \mathrm{~h}$ ) called attention to this phenomenon and pointed out that it occurred usually when convalescence was stormy, an observation that coincides in general with our experience. The significance of this secondary rise in serum phosphatase activity appears to depend largely upon the nature of the obstruction and the type of operation performed. In patients with stone in the common duct, the principal cause was infection such as subphrenic abscess involving the hilum of the liver (Case 133) or cholangeitis (Case 138). In patients with carcinomatous obstruction of the common duct, a late recurrence of serum phosphatase activity after establishment of internal biliary fistulae was associated with cholangeitis leading to closure of the stoma and to multiple liver abscesses (Case 10); with the development of liver metastases (Case 162); or with cholangeitis and liver metastases (Case 21). The association of increased serum phosphatase activity with complications attending the development of protracted biliary fistulae after cholecystectomy has already been illustrated by three case summaries.

Although our data are incomplete, there would appear to be a general correlation between the post-operative serum phosphatase level and the success of surgical procedures in the establishment of adequate biliary drainage. In this sense, serum phosphatase determinations may aid in the anticipation of certain post-operative complications, particularly in the development of cholangeitis or of liver metastases (the serum bilirubin level being an uncertain guide). Limitations in the use of the determination for this purpose are illustrated by instances in which con- valescence was without serious incident yet the fall in serum phosphatase was either very slow (Case 17) or was interrupted by a slight rise without apparent cause (Case 126). One patient (Case 139), who developed peritonitis postoperatively, showed a fall in serum phosphatase activity associated with a distinct rise in serum bilirubin. Necropsy disclosed extensive liver necrosis suggesting ' toxic' hepatitis.

C. Serum phosphatase determination as a means of early detection of metastases in malignancy. The liver is a site of predilection for distant metastases in many types of tumor but because of difficulties in the early detection of liver metastases by any means short of exploration, the recognition of metastatic liver involvement is frequently delayed until palpable nodules become obvious. Jaundice, as is well known, is a late and inconstant manifestation of metastatic malignancy. It has been our experience that usually before there is any demonstrable liver enlargement, the serum phosphatase activity of patients with liver metastases often shows a distinct rise $(14,12,1)$. On a number of occasions, the increased serum phosphatase level was the only objective evidence we could obtain of the presence of metastatic liver involvement demonstrated by exploration or necropsy shortly thereafter. However, the absence of a significant rise in the serum phosphatase level does not exclude the possibility of metastatic liver involvement since some patients with essentially normal serum phosphatase levels nevertheless proved to have liver metastases $(1,12,13,15)$, usually a few small nodules but sometimes more extensive invasion. Apparently, chance variations in the distribution and size of metastases affect the reliability of the method, particularly when few nodules are present, and limit the usefulness of the serum phosphatase determination for this purpose. Moreover, if jaundice is absent, it is necessary to exclude metastatic involvement of the skeleton (usually but not always possible by $\mathrm{x}$-ray) before concluding that increased serum phosphatase activity is due to liver metastases; though it is often immaterial, as when ablation of a primary tumor is contemplated, whether secondaries involve liver or skeleton, so long as they can be detected early.

It is our impression that, as emphasized by Meranze, Meranze and Rothman (15), valid early 
evidence for metastases may be afforded by the finding of a definitely elevated serum phosphatase level in patients known to have malignancy. This obviously does not apply if other causes of increased serum phosphatase activity (Paget's disease, etc.) are present or if the primary tumor itself may be responsible for such an increase (osteogenic sarcoma, primary tumors obstructing the biliary tract). It should be kept in mind that the serum phosphatase level is not affected by metastases to such organs as lungs and may not be significantly affected by either liver or bone metastases (particularly of the osteolytic type) or both (see Case 320).

\section{Mechanisms regulating the behavior of the serum phosphatase level in disease of the liver and biliary tract}

According to the prevailing concept (10), " alkaline" serum phosphatase ${ }^{8}$ originates for the most part in bone-producing cells (an assumption based chiefly upon the high phosphatase activity of bone) and, after escaping into the circulating fluids, is excreted in the bile (an assumption based upon the high phosphatase activity of the bile). Clinical experience, on the whole, is in good agreement with this theory. Serum phosphatase determinations in a wide variety of diseases have shown, empirically, that appreciable elevations in serum phosphatase activity are observed consistently in only two general pathological states: (1) diseases of the skeletal system in which there is active, widespread formation of bone or cartilage $(11,12,13,17) ;(2)$ diseases of the liver and biliary system in which there is obvious or presumptive impingement upon the excretory channels (biliary tract), whether extraor intrahepatic. That skeletal disorders characterized by increased osteogenesis cause elevated serum phosphatase levels is understandable, on the basis of the experimental evidence for the osseous origin of "alkaline" phosphatase, as due to increased formation of the enzyme. That hepatic disorders of the obstructive type cause increased serum phosphatase activity would be anticipated as a result of retention of the enzyme

\footnotetext{
${ }^{8}$ For the sake of simplicity we have referred to the serum phosphatases as "phosphatase." In reality, at least one "alkaline" and at least one "acid" phosphatase system is present in serum.
}

due to blocking of its excretory channel, the biliary tract. The prevailing concept therefore affords an explanation for the occurrence of a common phenomenon (increased serum phosphatase activity) in diseases that are otherwise extremely heterogeneous in character.

There is a diversity of opinion regarding the validity of the " retention" theory as applied to the increased serum phosphatase activity observed in some hepatic disorders. It is wholly probable that even if blocking of the excretory biliary channels results in retention of phosphatase in the serum, other factors also affect the serum phosphatase level in obstructive jaundice. It is difficult otherwise to explain the wide range in serum phosphatase activity in different patients each having complete and protracted obstruction of the common bile duct (from 113.1 to 9.6 Bodansky units per $100 \mathrm{cc}$. in our cases of carcinoma of the head of the pancreas). Evidently, the level of serum phosphatase at which equilibrium is re-established in the blood following common duct obstruction does not depend solely upon the degree of obstruction. It would seem likely that the rate of phosphatase formation and the adequacy of other methods of disposing of serum phosphatase (by mechanisms as yet unknown) play a rôle here. That these other factors are operative does not imply, however, that the "retention" theory is invalid.

Several alternative explanations have been offered in lieu of the "retention" theory. Thannhauser and his associates have interpreted their clinical and experimental studies $(18,19)$ to signify that the increased serum phosphatase activity observed in sundry diseases, including obstructive jaundice, is due not to increased concentration of the enzyme in the blood but rather to the effect of an activator on the enzyme. This hypothesis is based upon their observation that ascorbic acid activates serum phosphatase (20), a phenomenon subsequent studies $(21,22)$ proved to be an artefact. The activity of "alkaline" phosphatase is slightly inhibited by bile salts (23).

Another explanation for the behavior of the serum phosphatase level in diseases of the liver and biliary tract lies in the possible hepatogenous origin of at least part of the "alkaline" phosphatase content of serum. Bodansky has shown (24) that nutritional factors may influence the 
" alkaline" phosphatase activity of the serum and has raised the question of extra-osseous sources of the enzyme (25). Liver tissue is known to contain appreciable amounts of both "alkaline" and " acid" phosphatases. It is possible that the behavior of the serum phosphatase in hepatic disease is due not to retention of a phosphatase of osseous origin but to varying effects of hepatic disease upon the elaboration and secretion of phosphatase by the liver parenchyma. Much of the evidence now available, both experimental and clinical, is interpretable either way. Current discussion along these lines is reminiscent of the controversy which prevailed regarding the hepatic vs. extra-hepatic origin of the bile pigments until incontrovertible proof of their chiefly extrahepatic origin was obtained (26).

No such definitive evidence is now available, one way or the other, concerning the validity of the "retention" theory of the behavior of serum phosphatase levels in disease of the liver and biliary tract. Such evidence must be obtained by proper experiment. But so far as clinical observations go, the distribution of our data on adults (Table VIII) is consistent, on the whole, with the "retention" theory. Gross obstruction of the common bile duct quite regularly results in markedly increased serum phosphatase activity, the exceptions occurring chiefly with incomplete or intermittent obstruction. Interposition of masses in the liver substance (tumor nodules, liver abscess, etc.) that might block off major intrahepatic biliary passages likewise leads to elevated serum phosphatase values. Hepatogenous or "catarrhal" jaundice usually causes relatively little increase in serum phosphatase activity as compared with the degree of hyperbilirubinemia; not more than might well be due to varying intrahepatic obstruction of the finer biliary radicles. Hemolytic jaundice does not ordinarily affect the serum phosphatase level. The varying serum phosphatase levels observed in jaundice due to hepatotoxic drugs accord with other criteria in patients with high levels and are all indicative of the possibility of intrahepatic biliary obstruction. Fibrosis of the portal areas (or about the central veins) seems not to disrupt the biliary tract in most instances, judging by the preponderance of cases with little or no jaundice and comparatively little increase in serum phosphatase activity; ap- parently new bile duct proliferation maintains the integrity of the excretory channels. But when disorganization of the biliary tract, with jaundice, occurs in Laënnec's cirrhosis (due to complications like infection or neoplastic degeneration), the serum phosphatase level rises.

On the other hand, it is clear that markedly increased serum phosphatase activity may occur with little or no hyperbilirubinemia (as, for instance, with metastatic liver malignancy) and this dissociation has seemed to some $(27,28)$ incompatible with the "retention" theory: both phosphatase and bilirubin being constituents of bile, obstruction of the biliary tract sufficient to cause retention of phosphatase ought to be associated with a comparable degree of bilirubin retention. This would follow, of course, if the blood levels of both bilirubin and phosphatase depended solely upon their common rate of excretion in the bile. However, bile pigments are excreted in the urine when there is biliary obstruction with retention of bile in the blood, whereas the human kidney appears to be impermeable to "alkaline" serum phosphatase. ${ }^{4}$ This difference with respect to renal excretion affords a possible explanation for the occurrence of increased serum phosphatase activity with little or no jaundice, a dissociation which does not seem to us to disqualify the "retention" theory. In hepatitis, the absence of appreciable increase in phosphatase activity, despite marked hyperbilirubinemia due to blocking of bile pigments by the disordered parenchyma, suggests possible shunting of the enzyme around the polygonal cells.

The increased serum phosphatase activity sometimes observed in patients with external biliary fistulae draining bile likewise appears to be incongruous with the " retention" theory, since under these circumstances bile, and therefore

4 That is, the "alkaline" phosphatase activity of human urine is negligible in jaundiced (or normal) human subjects. Interestingly enough, in the cat, the one species in which "alkaline" phosphatase is known to be present in appreciable amounts in the urine (29), ligation of the common bile duct causes little or no rise in serum phosphatase activity (30).

In passing, it might be noted that dissociation of serum bilirubin and phosphatase is not peculiar to phosphatase among bile constituents. For example, a similar dissociation between serum bilirubin and total cholesterol values is the rule in hepatogenous jaundice. 
phosphatase, is certainly being excreted. The validity of this inconsistency would seem to depend upon whether or not the excretion of phosphatase in a given instance is adequate, always a difficult matter to appraise. The fairly consistent occurrence of clinical complications, when such dissociation was observed by us, leads to the suspicion that drainage under those circumstances may not be as adequate as would appear. It is interesting to note in this connection that patients with seemingly free drainage of bile through external fistulae may show other peculiarities such as increased serum cholesterol (31) and rather marked increase in bromsulfalein retention (9).

A more convincing inconsistency of the "retention" theory encountered in our clinical material, however, was that presented by infants with jaundice due to congenital atresia of the bile ducts. In spite of typical obstructive jaundice, the serum phosphatase level in this condition has been found to be within or only moderately above the normal range in infants. We obtained values of 11.1 and 6.3 Bodansky units per $100 \mathrm{cc}$. respectively in 2 such previously recorded instances (Cases 112 and 113; see Donovan (32) for clinical details). Similar results have been obtained by other investigators $(3 \mathrm{f}, 3 \mathrm{i})$. Another case reported here (Case 173) showed a level of 17.1 Bodansky units, a value which we regard as definitely elevated but probably less than might be anticipated in obstructive jaundice at this age period. It remains to be determined whether these unexpected results signify that the "retention" theory is untenable or whether they are ascribable to some as yet unknown peculiarity of the phosphatase metabolism in the infant.

\section{SUM MARY}

Our experience during the period 1933 to 1939 with serum phosphatase determinations (Bodansky method) in disorders of the liver and biliary tract is summarized. An analysis was made of the results in over 300 adult patients in whom the diagnosis, apart from the hepatitides, could be established at operation or autopsy.

Of 79 adults with proven obstruction of the common bile duct, 72 (roughly 90 per cent) had serum phosphatase levels more than 10 Bodansky units per $100 \mathrm{cc}$. In the "hepatitis" group, 82 of 107 adult cases had serum phosphatase levels less than 10 Bodansky units per $100 \mathrm{cc}$; but if, as we have proposed, patients with jaundice following exposure to hepatotoxic agents be segregated from the "catarrhal" jaundice group, then 62 of the 69 latter cases (roughly 90 per cent) had serum phosphatase levels less than 10 Bodansky units per 100 cc. There is a striking dispersion in the serum phosphatase values of patients with jaundice following exposure to hepatotoxic agents, especially arsphenamine. This dispersion may have clinical significance.

Hemolytic jaundice was associated with normal serum phosphatase values. Of 44 patients with advanced cirrhosis (exclusive of biliary cirrhosis), 34 had serum phosphatase values less than 9 Bodansky units per 100 cc. Forty-seven patients with proven neoplastic involvement of the liver showed a wide dispersion in serum phosphatase levels, depending apparently upon the number and location of metastases. Chronic passive congestion of the liver caused little or no elevation in serum phosphatase activity; liver abiscess was usually associated with distinctly increased values.

We find the determination of serum phosphatase activity of limited but definite value as a supplementary aid to the clinical differentiation of the several types of jaundice. It is useful particularly in ruling out obstruction of the extrahepatic biliary tract, an improbable cause of jaundice in patients with serum phosphatase values less than 10 Bodansky units per $100 \mathrm{cc}$. When applied to the differential diagnosis of jaundice, the following sources of error should be recognized: (a) overlapping of values in the obstructive and hepatogenous groups of jaundice (about 10 per cent in either direction, in our experience) ; (b) unspecificity, as certain skeletal disorders increase serum phosphatase activity; $(c)$ inapplicability to jaundice in children, particularly in congenital atresia of the bile duct.

The determination of serum phosphatase activity may be useful also in anticipating certain complications following surgery of the biliary tract. Pre- and post-operative determinations in 24 patients with obstructive jaundice disclosed a distinct correlation between post-operative serum phosphatase trends and the post-operative clinical course. 
Furthermore, the determination of serum phosphatase activity is of some value in the relatively early detection of liver or skeletal metastases in patients known to have malignancy.

Possible mechanisms regulating the serum phosphatase level in disorders of the liver and biliary tract are considered, with special reference to the "retention" theory. To judge from our empirical clinical experience, the serum phosphatase level in the adult is a sensitive criterion of the integrity of the excretory biliary channels, extraand intra-hepatic, affording positive evidence for obstruction. It is suggested that the determination be employed to complement "liver function" tests, which measure impairment of a given function of the liver parenchyma but provide merely negative evidence for obstruction; and the dye retention tests which are inapplicable in jaundiced patients.

We are indebted to the many members of the Medical and Surgical Staffs who permitted study of their cases.

\section{BIBLIOGRAPHY}

1. Flood, C. A., Gutman, E. B., and Gutman, A. B., Phosphatase activity, inorganic phosphorus and calcium of serum in disease of liver and biliary tract; study of 123 cases. Arch. Int. Med., 1937, $59,981$.

2. Roberts, W. M., Blood phosphatase and van den Bergh reaction in differentiation of several types of jaundice. Brit. M. J., 1933, 1, 734.

3. a. Bodansky, A., and Jaffe, H. L., Phosphatase studies: IV. Serum phosphatase of non-osseous origin. Significance of variations of serum phosphatase in jaundice. Proc. Soc. Exper. Biol. and Med., 1933, 31, 107.

b. Greene, C. H., Shattuck, H. F., and Kaplowitz, L., Phosphatase content of blood serum in jaundice. J. Clin. Invest., 1934, 13, $10 \% 9$.

c. Herbert, F. K., Plasma phosphatase in various types of jaundice. Brit. J. Exper. Path., 1935, $16,365$.

d. Anderson, R. G., Plasma phosphatase in jaundice. St. Barth. Hosp. Rep., 1935, 68, 221.

e. Rothman, M. M., Meranze, D. R., and Meranze, T., Blood phosphatase as aid in differential diagnosis of jaundice. Am. J. M. Sc., 1936, 192, 526.

f. Cantarow, A., and Nelson, J., Serum phosphatase in jaundice. Arch. Int. Med., 1937, 59, 1045.

g. Shay, H., and Fieman, P., Value of combined study of newer laboratory test in differential diagnosis of toxic and obstructive jaundice including blood phosphatase, cholesterol partition, galactose tolerance and glucose tolerance. Am. J. Digest. Dis. and Nutrition, 1938, 5, 597.

h. Meranze, T., Meranze, D. R., and Rothman, M. M., Review of the value of serum phosphatase in diseases of the liver. Rev. of Gastroenterology, 1939, $6,254$.

i. Giordano, A. S., Wilhelm, A., and Prestrud, M. C., The serum phosphatase in the differential diagnosis of obstructive jaundice. Am. J. Clin. Path., 1939, 9, 226.

j. Winkelman, L., and Schiffman, A., Clinical significance of variations in serum phosphatase in hepatic and biliary disorders. Arch. Int. Med., 1939, 64, 348.

4. Bodansky, A., Phosphatase studies: II. Determination of serum phosphatase. Factors influencing accuracy of determination. J. Biol. Chem., 1933, 101, 93.

5. Thannhauser, J. S., and Andersen, E., Methodik der quantitativen Bilirubinbestimmung im menschlichen Serum: Ueber die Ehrlich-Pröscher'sche Reaktion. Deutsches Arch. f. klin. Med., 1921, 137, 179.

6. Hanger, F. M., Serological differentiation of obstructive from hepatogenous jaundice by flocculation of cephalin-cholesterol emulsions. J. Clin. Invest., 1939, 18, 261.

7. Connor, C. L., Etiology and pathogenesis of alcoholic cirrhosis of liver. J. A. M. A., 1939, 112, 387.

8. Greene, C. H., and Shattuck, H. F., Clinical use of tests of hepatic function. Am. J. Digest. Dis. and Nutrition, 1934, 1, 505.

9. Snell, A. M., and Magath, T. B., Use and interpretation of tests for liver function; clinical review. J. A. M. A., 1938, 110, 167.

10. Kay, H. D., Phosphatase in growth and disease of bone. Physiol. Rev., 1932, 12, 384.

11. Bodansky, A., and Jaffe, H. L., Phosphatase studies. III. Serum phosphatase in diseases of bone: interpretation and significance. Arch. Int. Med., 1934, 54, 88.

12. Gutman, A. B., Tyson, T. L., and Gutman, E. B., Serum calcium, inorganic phosphorus and phosphatase activity in hyperparathyroidism, Paget's disease, multiple myeloma and neoplastic disease of bones. Arch: Int. Med., 1936, 57, 379.

13. Franseen, C. C., Simmons, C. C., and McLean, R., The phosphatase determination in the differential diagnosis of bone lesions. Surg., Gynec., and Obst., 1939, 68, 1038.

14. Gutman, A. B., Swenson, P. C., and Parsons, W. B., Differential diagnosis of hyperparathyroidism. J. A. M. A., 1934, 103, 87.

15. Meranze, D. R., Meranze, T., and Rothman, M. M., Serum phosphatase as aid in diagnosis of metastasis of cancer to liver. Pennsylvania M. J., 1938, 41,1160 .

16. Gutman, A. B., and Gutman, E. B., "Acid" phosphatase activity of serum of normal human subjects. Proc. Soc. Exper. Biol. and Med., 1938, 38, 470. 
17. Woodard, H. Q., Twombly, G. H., and Coley, B. L., Study of serum phosphatase in bone disease. J. Clin. Invest., 1936, 15, 193.

18. Thannhauser, S. J., Reichel, M., Grattan, J. F., and Maddock, S., Studies on serum phosphatase activity. V. Studies concerning increased serum phosphatase values in disease. J. Biol. Chem., 1937, 121, 727.

19. Thannhauser, S. J., Reichel, M., Grattan, J. F., and Maddock, S., Studies on serum phosphatase activity. VI. Influence of sera with high phosphatase activity on normal sera. J. Biol. Chem., 1938, 124, 631.

20. Thannhauser, S. J., Reichel, M., and Grattan, J. F., Studies on serum phosphatase activity. I. Ascorbic acid activation on serum phosphatase. J. Biol. Chem., 1937, 121, 697.

21. King, E. J., and Delory, G. E., Ascorbic acid and phosphatase activity. Biochem. J., 1938, 32, 1157.

22. Thannhauser, S. J., Reichel, M., and Grattan, J. F., Effect of ascorbic acid on $\beta$-glycerophosphate. Biochem. J., 1938, 32, 1163.

23. Bodansky, O., Are phosphatases of bone, kidney, intestine, and serum identical? Use of bile acids in their differentiation. J. Biol. Chem., 1937, 118, 341.
24. Bodansky, A., and Jaffe, H. L., Effects of diet and fasting on plasma phosphatase. Proc. Soc. Exper. Biol. and Med., 1931, 29, 199.

25. Bodansky, A., Non-osseous origins of serum phosphatase: The liver. Enzymologia, 1937, 3, 258.

26. Mann, F. C., and Bollman, J. L., Jaundice; review of some experimental investigations. J. A. M. A., 1935, 104, 371.

27. Cantarow, A., Biliary stasis and decompression; review of recent contributions. Internat. Clin., 1938, $1,272$.

28. Cantarow, A., and Trumper, M., Clinical Biochemistry. W. B. Saunders Co., Philadelphia, 1939, 2nd edition.

29. Flood, C. A., Gutman, E. B., and Gutman, A. B., Serum and urine phosphatase activity in cat after ligation of common bile duct. Am. J. Physiol., 1937, 120, 696.

30. Cantarow, A., Stewart, H. L., and McCool, S. G., Serum phosphatase in cats with total bile stasis. Proc. Soc. Exper. Biol. and Med., 1936, 35, 87.

31. Epstein, E. Z., and Greenspan, E. B., Clinical significance of cholesterol partition of blood plasma in hepatic and in biliary diseases. Arch. Int. Med., 1936, 58, 860.

32. Donovan, E. J., Congenital atresia of the bile ducts. [See cases 15 and 14.] Ann. Surg., 1937, 106, 737. 